\title{
Porezni klin u Hrvatskoj, Austriji, Mađarskoj, Poljskoj i Grčkoj
}

Onorato, Marin

Source / Izvornik: Odabrani prijevodi, 2016, 7, 1 - 24

Journal article, Published version

Rad u časopisu, Objavljena verzija rada (izdavačev PDF)

https://doi.org/10.3326/op.41

Permanent link / Trajna poveznica: https:/urn.nsk.hr/urn:nbn:hr:242:404988

Rights / Prava: Attribution-NonCommercial-NoDerivatives 4.0 International/ImenovanjeNekomercijalno-Bez prerada 4.0 međunarodna

Download date / Datum preuzimanja: 2023-04-26

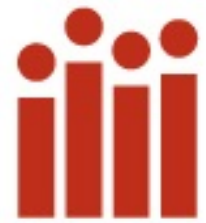

Repository / Repozitorij:

Institute of Public Finance Repository

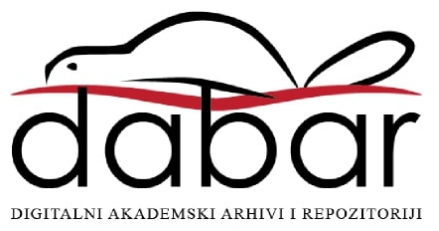


Institut za

javne financije

Smičiklasova 21 | Zagreb

www.ijf.hr | ured@ijf.hr

T: 01/4886-444 | F: 01/4819-365

\section{ODABRANI}

PRIJEVODI

\section{BR. 41}

\section{6.}

ISSN $1847-7445$

\section{Porezni klin u HrVatskoJ, AustriJi, MAĐARSKOJ, POLJSKOJ I GRČKOJ}

MAG. MATH MARIN ONORATO*

PRETHODNO PRIOPĆENJE**

JEL: H21, H24, J38

DOI: $10.3326 /$ op. 41

\section{SAŽETAK}

U ovom radu uspoređuje se porezno opterećenje dohotka od rada u Hrvatskoj, Austriji, Grčkoj, Mađarskoj i Poljskoj u 2013. godini. Korištenjem OECD-ove Taxing Wages metodologije izračunavaju se neto prosječni porezni klin, neto prosječna porezna stopa i drugi pokazatelji, za hipotetske jedinice s različitim iznosima bruto plaće. Za samce bez djece Hrvatska ima najniži porezni klin za plaće ispod prosječne bruto plaće, a za plaće iznad prosječne najniži je klin u Poljskoj. Zahvaljujući progresivnom rasporedu stopa u sustavu poreza na dohodak, porezni klin za samca u Hrvatskoj doseže 50\% pri plaći od 400\% prosječne bruto plaće, čime se izjednačava s Austrijom, Grčkom i Mađarskom. Sličan obrazac se može uočiti za parove s dvoje djece.

Ključne riječi: porezno opterećenje, porezni klin, prosječna porezna stopa, porez na dohodak, doprinosi za socijalno osiguranje, Hrvatska, Austrija, Mađarska, Poljska, Grčka citirati: Onorato, M., 2016. Tax wedge in Croatia, Austria, Hungary, Poland and Greece. Financial Theory and Practice, 40 (2), str. 265-288. Dostupno na: $<$ http://www.fintp.hr/upload/files/ftp/ 2016/2/onorato.pdfs.
Svi Odabrani prijevodi dostupni su na: http://www.ijf.hr/hr/publikacije/casopi si/12/odabrani-prijevodi/111/
* Autor zahvaljuje anonimnim recenzentima na njihovim korisnim komentarima i prijedlozima. Ovaj članak dio je posebnog izdanja časopisa Financial Theory and Practice, posvećenom usporedbi poreznog klina na dohodak od rada u Hrvatskoj i drugim zemljama EU-a. Članci u tom izdanju su nastali na temelju studentskog istraživačkog projekta poduzetog 2015. Predgovor posebnom izdanju (Urban, 2016.) opisuje motivaciju istraživačkog projekta, objašnjava najvažnija metodološka pitanja te pruža pregled literature o mjerenju poreznog klina u Hrvatskoj.

** Primljeno: 31. siječnja 2016.

Prihvaćeno: 31. ožujka 2016.

\section{Marin ONORATO}

e-mail: marin.onorato@gmail.com 


\section{UvOD}

U ovom radu analizira se porezno opterećenje dohotka od rada u zemljama EU-a, a odnosi se na Hrvatsku, Austriju, Mađarsku, Poljsku i Grčku. U radu se detaljno govori o sastavnicama oporezivanja dohotka rada u spomenutim zemljama: porezima na dohodak, doprinosima poslodavaca i posloprimaca za socijalno osiguranje te socijalnim naknadama za obitelj. Zatim se, zasebno za svaku zemlju, prikazuju izračuni nekoliko pokazatelja poreznog opterećenja, definiranih sukladno Taxing Wages metodologiji. Izračuni spomenutih pokazatelja napravljeni su uz pomoć autorovog mikrosimulacijskog modela koji za hipotetske obitelji u pet zemalja izračunava iznose poreza, doprinosa i socijalnih naknada.

Ključni cilj rada je usporediti prosječno porezno opterećenje u promatranim zemljama. To se čini za osam hipotetskih obitelji koje definira OECD (2014.). Dodatno se analiziraju dva skupa hipotetskih jedinica - samci i parovi s dvoje djece - kojima se dodjeljuju bruto plaće u relativno širokom rasponu. Potonje se čini kako bi se stekao uvid u porezno opterećenje pri višim dohocima. Rad je organiziran na sljedeći način. U drugom dijelu prikazane su osnovne informacije o korištenoj metodologiji. Treći dio sadrži detaljan prikaz sustava oporezivanja rada u promatranim zemljama te izračune pokazatelja poreznog opterećenja. U četvrtom dijelu uspoređuju se neto prosječni porezni klin za samce i parove s djecom za široki raspon bruto plaća. Na kraju slijedi zaključak.

\section{Metodologija}

\subsection{Prosječna Plaća}

Jedan od osnovnih koncepata Taxing Wages metodologije (OECD, 2014.) je prosječna bruto plaća (AGW; average gross wage) u određenoj zemlji, koja se izračunava na temelju podataka za određene sektore, a ne za cijelo gospodarstvo. AGW služi u definiranju hipotetskih jedinica, gdje se odraslim osobama pridružuju bruto plaće jednake određenim postotcima AGW-a. Tablica 1 prikazuje iznose AGW-a koji se koriste u istraživanju, a odnose se na 2013.

\section{TABLICA 1.}

Godišnje prosječne bruto plaće u odabranim zemljama, 2013.

\begin{tabular}{llcc} 
& AGW u nacionalnoj valuti & Tečaj & AGW (u eurima) \\
\hline Hrvatska & HRK 93.180 & HRK/EUR $=7,5735$ & 12.303 \\
\hline Austrija & EUR 41.693 & 1 & 41.693 \\
\hline Mađarska & HUF 2.914 .514 & HUF/EUR $=303,0270$ & 9.618 \\
\hline Poljska & PLN 41.442 & PLN/EUR $=4,1945$ & 9.880 \\
\hline Grčka & EUR 20.604 & 1 & 20.604 \\
\hline
\end{tabular}

Napomena: za Austriju se u godišnju plaću uračunava 14 mjesečnih plaća zbog prakse da poslodavci isplaćuju božićnicu i naknadu za odmor u iznosima prosječnih mjesečnih plaća.

Izvor: (1) AGW - za Hrvatsku: autorov izračun prema DZS (2015.) i Urban (2016.); za ostale zemlje: OECD (2014.); (2) tečaj za Hrvatsku: prosječni tečaj HRK/EUR (HNB, 2016.); za Mađarsku i Poljsku: OECD (2014.). 


\subsection{HIPOTETSKE JEDINICE}

Hipotetske jedinice za koje se izračunavaju pokazatelji sačinjene su od jedne ili dvije odrasle osobe (parovi), a mogu biti bez djece ili s dvoje djece. Tablica 2 prikazuje sastav svih osam hipotetskih jedinica.

\section{TABLICA 2.}

Obilježja promatranih tipova hipotetskih jedinica

\begin{tabular}{lcccc}
$\begin{array}{l}\text { Oznaka u ovom } \\
\text { radu }\end{array}$ & Odrasli članovi & Broj djece & $\begin{array}{c}\text { Supružnik I } \\
\text { (\% AGW-a) }\end{array}$ & $\begin{array}{c}\text { Supružnik II } \\
\text { (\% AGW-a) }\end{array}$ \\
\hline A-67-NC & Samac & 0 & $2 / 3 \times 100$ & - \\
\hline A-100-NC & Samac & 0 & 100 & - \\
\hline A-167-NC & Samac & 0 & $5 / 3 \times 100$ & - \\
\hline A-67-2C & Samac & 2 & $2 / 3 \times 100$ & ne radi \\
\hline 2A-100/0-2C & Par & 2 & 100 & $1 / 3 \times 100$ \\
\hline 2A-100/33-2C & Par & 2 & 100 & $2 / 3 \times 100$ \\
\hline $2 \mathrm{~A}-100 / 67-2 \mathrm{C}$ & Par & 2 & 100 & $1 / 3 \times 100$ \\
\hline $2 \mathrm{~A}-100 / 33-\mathrm{NC}$ & Par & 0 & 100 & \\
\hline
\end{tabular}

Napomena: kratice su zasnovane na engleskom jeziku. Značenje pojedinih simbola je sljedeće: AGW - average gross wage (prosječna bruto plaća); $A$ - adult (odrasla osoba); $N C$ - no children (bez djece); $2 C-2$ children (dvoje djece).

Izvor: OECD (2014.).

Prve tri hipotetske jedinice (A-67-NC, A-100-NC, A-167-NC) su samci bez djece čija je bruto plaća jednaka 2/3,100\% ili 5/3 AWG-a. Jedinica A-67-2C je samac s dvoje djece, čija je bruto plaća jednaka 2/3 AGW-a. Zatim su tu tri obitelji s dvoje djece (2A-100/0-2C, 2A-100/33-2C, 2A-100/672C), u kojima prvi supružnik ima bruto plaću u visini 100\% AWG-a, a drugi supružnik ima redom plaću jednaku 0,1/3 i 2/3 AWG-a. Konačno, tu je i par bez djece (2A-100/33-NC), u kojem prvi supružnik prima plaću od 100\% AWG-a, a drugi 1/3 AWG-a. U Hrvatskoj je za 2013. bila propisana minimalna plaća (Uredba o visini minimalne plaće za 2013. godinu) koja je veća od $33 \%$ prosječne bruto plaće no ta je činjenica zanemarena kako bi se vjerodostojno pratio OECD-ov model.

Osim spomenutih osam OECD-ovih tipičnih jedinica, u radu se koriste i dodatne jedinice. Prvi skup čine samci bez djece s različitim bruto plaćama, koje se kreću u rasponu od 50 do 500\% AGW-a. Drugi skup čine parovi s dvoje djece, pri čemu se koriste različite kombinacije plaća supružnika, tako da se ukupna bruto plaća obitelji kreće od 100\% AGW-a do 500\% AGW-a (za primjer vidjeti Grafikon 2).

\subsection{PoKAZATELJI POREZNOG OPTEREĆENJA}

U radu se koriste dva pokazatelja poreznog opterećenja: prosječni porezni klin i neto prosječna porezna stopa. Neto prosječni porezni klin (net average tax wedge) je omjer ukupnih neto poreznih davanja i ukupnog troška rada. Neto prosječna porezna stopa (net average tax rate) je omjer neto poreznih davanja posloprimca i bruto plaće.

Ukupni trošak rada, ukupna neto porezna davanja i neto porezna davanja posloprimca izračunavaju se pomoću formula (1), (2) i (3). 
Ukupni trošak rada

= bruto plaća

+ doprinosi poslodavca

+ porezi na platnu listu

Ukupna neto porezna davanja

= porezi na dohodak na svim razinama državne vlasti

+ doprinosi posloprimca

+ doprinosi poslodavca

+ porezi na platnu listu

- novčane naknade za obitelj

Neto porezna davanja posloprimca

= porezi na dohodak na svim razinama državne vlasti

+ doprinosi posloprimca

- novčane naknade za obitelj

Osim dvaju glavnih pokazatelja, u analizi su korištena još dva pokazatelja: prosječna stopa poreza na dohodak (omjer poreza na dohodak i bruto plaće) te prosječna stopa doprinosa posloprimca (omjer doprinosa posloprimca i bruto plaće).

Pri tome je važno naglasiti da se pod doprinose posloprimca i poslodavca uzimaju u obzir samo doprinosi koji se plaćaju općoj državi, dok su doprinosi uplaćeni u fondove izvan opće države isključeni iz analize. Primjerice, u Hrvatskoj postoje dva stupa mirovinskog osiguranja - prvi i drugi stup. Doprinosi posloprimca u prvi stup su prihodi opće države, a doprinosi za drugi stup su prihodi obveznih privatnih fondova. Stoga će prvi ući u izračun pokazatelja poreznog opterećenja, a drugi neće. O ovoj temi opširnije vidjeti u Urban (2016.), Blažić i Trošelj (2012), OECD (2014., 2015.).

\section{PREgLED OPOREZIVANJA RADA PO ZEMLJAMA}

\subsection{HRVATSKA}

\subsubsection{OSNOVNI ELEMENTI OPOREZIVANJA RADA U HRVATSKOJ}

U Hrvatskoj poslodavci i posloprimci plaćaju pet različitih doprinosa za socijalno osiguranje, čije stope u 2013. prikazuje Tablica 3. Najviša osnovica za obračun doprinosa postoji kod doprinosa za mirovinsko osiguranje za prvi stup, i godišnje iznosi 74.790 eura (Naredba o iznosima osnovica za obračun doprinosa za 2013. godinu). Za ostale doprinose nije određena najviša osnovica.

\section{TABLICA 3.}

Stope doprinosa za socijalno osiguranje (Hrvatska, 2013.)

\begin{tabular}{lcc} 
Doprinos & $\begin{array}{c}\text { Stopa za posloprimca } \\
\text { (\% bruto plaće) }\end{array}$ & $\begin{array}{c}\text { Stopa za poslodavca } \\
\text { (\% bruto plaće) }\end{array}$ \\
\hline Doprinos za prvi stup mirovinskog osiguranja & 15,0 & - \\
\hline Doprinos za drugi stup mirovinskog osiguranja & 5,0 & - \\
\hline Doprinos za zdravstveno osiguranje & - & 13,0 \\
\hline Doprinos za ozljede na radu & - & 0,5 \\
\hline Doprinos za zapošljavanje & - & 1,7 \\
\hline Ukupno & 20,0 & 15,2 \\
\hline
\end{tabular}

Izvor: Zakon o doprinosima (NN 84/08., 152/08., 94/09., 18/11., 22/12., 144/12., 148/13.). 
Osnovica poreza na dohodak jednaka je bruto plaći umanjenoj za doprinose za mirovinsko osiguranje i osobne odbitke. Osobni odbici jednaki su zbroju osnovnog osobnog odbitka i odbitaka za uzdržavane članove obitelji (Tablica 4).

\section{TABLICA 4.}

Osobni odbici (Hrvatska, 2013.)

\section{Osobni odbici}

Osnovni osobni odbitak

Odrasli uzdržavani član

Prvo dijete

Drugo dijete

Treće dijete

Četvrto dijete

Peto dijete

Dodatak za djelomičnu invalidnost

Dodatak za $100 \%$ invalidnost

Izvor: Zakon o porezu na dohodak.
Godišnji iznos (HRK)

26.400

13.200

13.200

18.480

26.400

36.960

50.160

7.920

26.400
Godišnji iznos (euro)

3.486

1.743

1.743

2.440

3.486

4.880

6.623

1.046

3.486

U 2013. godini postojala su tri razreda poreza na dohodak; njihov raspon i stope prikazuje Tablica 5.

\section{TABLICA 5.}

Razredi i stope poreza na dohodak (Hrvatska, 2013.)

Porezni razred (u eurima) Porezna stopa (\%)

\begin{tabular}{cc}
\hline$[0,3.486]$ & 12 \\
\hline$\langle 3.486,13.943]$ & 25 \\
\hline$\langle 13.943,+\infty\rangle$ & 40 \\
\hline
\end{tabular}

Izvor: Zakon o porezu na dohodak (NN 114/11., 22/12., 144/12., 43/13., 120/13., 125/13., 148/13.).

Prirez je porez koji se izračunava kao postotak iznosa poreza na dohodak, a stope prireza određuju gradovi i općine. U 2013. stope prireza kretale su se od 0\% do 18\% u Gradu Zagrebu. U ovoj analizi uzima se stopa prireza od $12 \%$, što otprilike odgovara ponderiranoj prosječnoj stopi prireza za sve gradove i općine u Hrvatskoj.

U Hrvatskoj se ne primjenjuju porezi na platnu listu. Od novčanih naknada za obitelj u analizu se uključuje doplatak za djecu, a predstavlja naknadu koju uz provjeru dohotka dodjeljuje središnja država. Iznos naknade ovisi o dohotku po članu obitelji, a način izračuna za obitelji s jednim ili dva djeteta prikazuje Tablica 6. Iznos naknade uvećava se za 15\% za djecu samohranog roditelja.

TABLICA 6.

Doplatak za djecu: godišnji razredi i iznosi (Hrvatska, 2013.)

Bruto dohodak po članu (euro)

Naknada po djetetu (euro)

\begin{tabular}{cc}
\hline$[0,875]$ & 474 \\
\hline$\langle 875,1.765]$ & 395 \\
\hline$\langle 1.765,2.635]$ & 316 \\
\hline
\end{tabular}

Izvor: Zakon o doplatku za djecu (NN 94/01., 138/06., 107/07., 37/08., 61/11., 112/12.). 


\subsubsection{POKAZATELJI POREZNOG OPTEREĆENJA}

Detaljne izračune za osam hipotetskih jedinica u Hrvatskoj prikazuju tablice A1, A2 i A3 u dodatku. Tablica 7 prikazuje pokazatelje poreznog opterećenja. Neto prosječni porezni klin samohranog roditelja s dvoje djece (A-67-2C) niži je za 12 postotnih bodova nego samca bez djece s istom plaćom (A-67-NC), što je posljedica djelovanja doplatka za djecu. Slično tome, razlika od 5 postotnih bodova se uočava između jedinica 2A-100/33-2C (s dvoje djece) i 2A-100/33-NC (bez djece), a ona je posljedica djelovanja odbitka za djecu.

\section{TABLICA 7.}

Pokazatelji poreznog opterećenja za osnovne hipotetske jedinice (Hrvatska, 2013.), u \%

\begin{tabular}{|c|c|c|c|c|c|c|c|c|}
\hline & $\begin{array}{l}\text { A-67- } \\
\text { NC }\end{array}$ & $\begin{array}{l}\text { A-100- } \\
\text { NC }\end{array}$ & $\begin{array}{l}\text { A-167- } \\
\quad \text { NC }\end{array}$ & $\begin{array}{l}\text { A-67- } \\
\text { 2C }\end{array}$ & $\begin{array}{c}2 A- \\
100 / \\
0-2 C\end{array}$ & $\begin{array}{c}2 A- \\
100 / 33 \\
-2 C\end{array}$ & $\begin{array}{c}2 A- \\
100 / 67 \\
-2 C\end{array}$ & $\begin{array}{c}2 A- \\
100 / 33 \\
-N C\end{array}$ \\
\hline Prosječna stopa poreza na dohodak & 5,04 & 10,34 & 15,17 & 0,00 & 0,47 & 1,78 & 3,44 & 7,76 \\
\hline $\begin{array}{l}\text { Prosječna stopa doprinosa } \\
\text { posloprimca }\end{array}$ & 20,00 & 20,00 & 20,00 & 20,00 & 20,00 & 20,00 & 20,00 & 20,00 \\
\hline Neto prosječna porezna stopa & 20,04 & 25,34 & 30,17 & 6,13 & 10,33 & 16,78 & 18,44 & 22,76 \\
\hline Neto prosječni porezni klin & 30,59 & 35,19 & 39,38 & 18,52 & 22,16 & 27,76 & 29,20 & 32,95 \\
\hline
\end{tabular}

Izvor: autorovi izračuni.

\section{GRAFIKON 1.}

Neto prosječni porezni klin i neto prosječna porezna stopa za samce bez djece (Hrvatska, 2013.), u \%

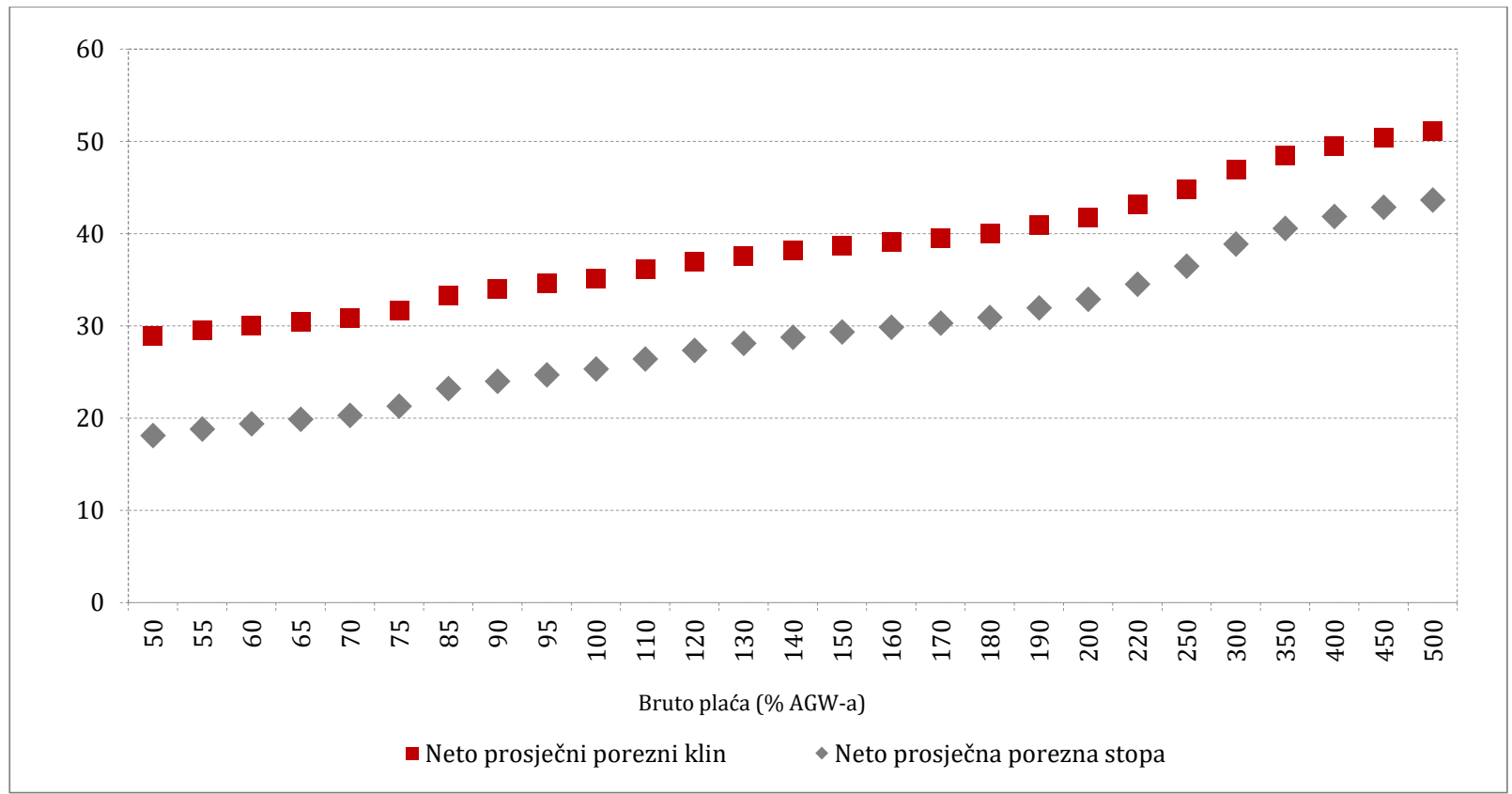

Izvor: autorovi izračuni.

Grafikoni 1 i 2 prikazuju kretanje neto prosječnog poreznog klina i neto prosječne porezne stope u širokom rasponu bruto plaća, za dodatne skupove hipotetskih samaca i parova s dvoje djece. Vidljivo je kako je sustav oporezivanja plaća u Hrvatskoj progresivan, odnosno prosječna porezna stopa povećava se s porastom bruto plaće. Neto prosječni porezni klin za samce u promatranom rasponu plaća raste od $29 \%$ do $51 \%$. Za parove s dvoje djece porezni klin raste do $42 \%$ za supružnike koji imaju bruto plaće od 300\% i 200\% AWG-a. Najniži porezni klin, od 22\%, imaju 
supružnici s bruto plaćama od 100\% i 0\% AWG-a. Može se primijetiti da klin naglo raste na 28\% za sljedeću prikazanu obitelj (100\% i 33\% AWG-a), a razlog toj promjeni je iščezavanje doplatka za djecu.

\section{GRAFIKON 2.}

Neto prosječni porezni klin i neto prosječna porezna stopa za parove s dvoje djece (Hrvatska, 2013.), $u \%$

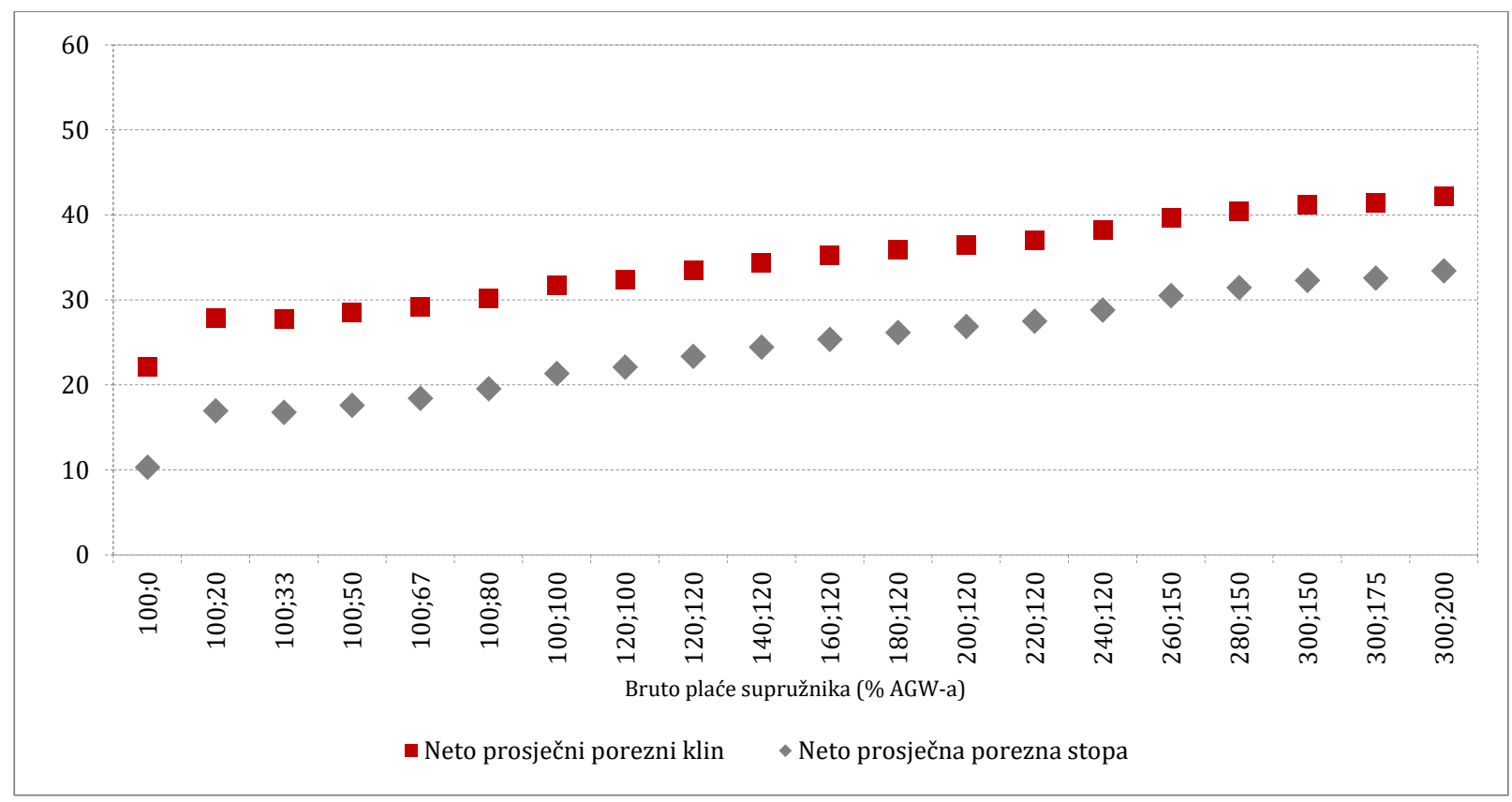

Izvor: autorovi izračuni.

\subsection{AUSTRIJA}

\subsubsection{OSNOVNI ELEMENTI OPOREZIVANJA RADA U AUSTRIJI}

Tablica 8 prikazuje doprinose za socijalno osiguranje u Austriji i njihove stope. Najviša osnovica za obračun doprinosa na osnovnu plaću godišnje iznosi 52.800 eura, a za dodatke plaći vrijedi najviši iznos od 8.800 eura.

\section{TABLICA 8.}

Stope doprinosa za socijalno osiguranje (Austrija, 2013.)

\begin{tabular}{lcc} 
Naziv doprinosa & $\begin{array}{c}\text { Doprinos posloprimca } \\
\text { (u \% bruto plaće) }\end{array}$ & $\begin{array}{c}\text { Doprinosi poslodavca } \\
\text { (u \% bruto plaće) }\end{array}$ \\
\hline Zdravstveno osiguranje & 3,95 & 3,70 \\
\hline Osiguranje za nezaposlenost & $(\mathrm{a})$ & 3,00 \\
\hline Mirovinsko osiguranje & 10,25 & 12,55 \\
\hline Osiguranje od nesreće & - & 1,40 \\
\hline Doprinos za komoru rada & 0,50 & - \\
\hline Doprinos za zgradu & $0,50(\mathrm{~b})$ & 0,50 \\
\hline Osiguranje od bankrota & - & 0,55 \\
\hline
\end{tabular}

Napomene: (a) osiguranje od nezaposlenosti ovisi o mjesečnim primanjima pa tako stopa iznosi: 0\% za mjesečnu bruto plaću manju od 1.219 eura, 1\% do 1.330 eura, 2\% do 1.497 eura i 3\% za sve bruto plaće veće od 1.497 eura; (b) doprinos za komoru rada te doprinos za zgradu ne plaćaju se u slučaju dodataka kao što su bonus i naknada za odmor.

Izvor: OECD (2014.). 
S obzirom na navedeno, doprinosi posloprimca ovise o mjesečnoj bruto plaći te se kreću između 15,2\% i 18,2\% bruto dohotka, doprinosi na božićnicu i naknadu za odmor iznose između 14,2\% i $17,2 \%$ bruto dohotka, a doprinosi poslodavca iznose $21,7 \%$ bruto dohotka za sve bruto plaće. Tablica 9 detaljno navodi olakšice u sustavu poreza na dohodak u Austriji.

\section{TABLICA 9.}

Umanjenja osnovice poreza na dohodak (Austrija, 2013.)

(1) Socijalni doprinosi zaposlenika te socijalni doprinosi vezani za božićnicu i naknadu za odmor: u punom iznosu

(2) Odbitak vezan uz posao: 132 eura

(3) Osnovni godišnji odbitak: 60 eura

(4) Odbitak za djecu: 220 eura po djetetu ako se priznaje za samo jednog supružnika ili 132 eura po djetetu ako olakšicu koriste oba roditelja

(5) Odbitak u oporezivanju božićnice i naknade za odmor: 620 eura Izvor: OECD (2014.).

U Austriji se primjenjuje raščlanjena progresija koja se primjenjuje i u Hrvatskoj. Porezne razrede i porezne stope navodi Tablica 10.

TABLICA 10.

Razredi i stope poreza na dohodak (Austrija, 2013.)

Porezni razred (u eurima)

Porezna stopa (\%)

\begin{tabular}{cc}
\hline$[0,11.000]$ & 0 \\
\hline$\langle 11.000,25.000]$ & 36,50 \\
\hline$\langle 25.000,60.000]$ & 43,21 \\
\hline$\langle 60.000,+\infty\rangle$ & 50,00 \\
\hline
\end{tabular}

Izvor: KPMG (2014.).

Nakon što se izračuna porezna obveza, pojedini obveznici mogu umanjiti obvezu za iznos "umanjenja poreza" (tax credit). Postoji tri vrste umanjenja poreza, odnosno osnovno umanjenje poreza za zaposlenika (54 eura godišnje), umanjenje poreza za troškove prijevoza (291 euro godišnje) te umanjenje poreza koje prima glava obitelji ili samohrani roditelj (godišnje 494 eura za prvo dijete, 175 eura za drugo dijete i 220 eura za svako sljedeće). Ukupno umanjenje poreza može biti najviše za 110 eura veće od početno izračunatog poreza na dohodak.

Porez na platnu listu u Austriji se izdvaja u slučaju da bruto dohodak od nesamostalnog rada prelazi 1.095 eura. Dijeli se u dvije stavke: doprinos za izjednačavanje obiteljskih mogućnosti koji iznosi 4,5\% bruto place, te porez za zajednicu koji iznosi 3\% bruto plaće.

U Austriji je predviđen doplatak za djecu koji ovisi o broju djece i njihovoj dobi. U radu uzimamo da djeca imaju između 10 i 15 godina. Fiksna naknada za dvoje djece iznosi 4.897 eura.

\subsubsection{POKAZATELJI POREZNOG OPTEREĆENJA}

Tablica 11. prikazuje pokazatelje poreznog opterećenja u Austriji. Prosječna stopa poreza na dohodak raste s bruto dohotkom što govori da je porez na dohodak progresivan. Treba napomenuti da se u ovakvim usporedbama uvijek razmatraju jednaki subjekti, dakle, samci bez djece ili parove s dvoje djece. Doprinosi su proporcionalni, osim kod većih plaća, kada postaju regresivni. Porezni 
klin samohranog roditelja s dvoje djece (A-67-2C) niži je za 16 postotnih bodova nego samca bez djece s istom plaćom (A-67-NC), što svjedoči o djelovanju poreznih olakšica i novčanih naknada namijenjenima obiteljima s djecom.

\section{TABLICA 11.}

Pokazatelji poreznog opterećenja za osnovne hipotetske jedinice (Austrija, 2013.), u \%

\begin{tabular}{|c|c|c|c|c|c|c|c|c|}
\hline & $\begin{array}{l}\text { A-67- } \\
\text { NC }\end{array}$ & $\begin{array}{l}\text { A-100- } \\
\text { NC }\end{array}$ & $\begin{array}{l}\text { A-167- } \\
\text { NC }\end{array}$ & $\begin{array}{l}\text { A-67- } \\
2 C\end{array}$ & $\begin{array}{c}2 A- \\
100 / 0 \\
-2 C\end{array}$ & $\begin{array}{c}2 A- \\
100 / 33- \\
2 C\end{array}$ & $\begin{array}{c}2 \mathrm{~A}- \\
100 / 67 \\
-2 \mathrm{C}\end{array}$ & $\begin{array}{c}2 A- \\
100 / 33 \\
\text {-NC }\end{array}$ \\
\hline $\begin{array}{l}\text { Prosječna stopa poreza na } \\
\text { dohodak }\end{array}$ & 10,23 & 16,24 & 22,93 & 7,24 & 14,18 & 11,64 & 13,53 & 11,98 \\
\hline $\begin{array}{l}\text { Prosječna stopa doprinosa } \\
\text { posloprimca }\end{array}$ & 18,06 & 18,06 & 16,01 & 18,06 & 18,06 & 17,31 & 18,06 & 17,31 \\
\hline Neto prosječna porezna stopa & 28,29 & 34,29 & 38,94 & 7,68 & 20,49 & 20,14 & 24,54 & 29,29 \\
\hline Neto prosječni porezni klin & 44,46 & 49,12 & 51,92 & 28,51 & 38,42 & 38,15 & 41,56 & 45,24 \\
\hline
\end{tabular}

Izvor: OECD (2014.) i autorovi izračuni.

Grafikoni 3 i 4 prikazuju kretanje neto prosječnog poreznog klina i neto prosječne porezne stope u širokom rasponu bruto plaća, za dodatne skupove hipotetskih samaca i parova s dvoje djece. Kod samaca (Grafikon 3) može se uočiti da nakon što bruto plaća dosegne 160\% prosječne bruto plaće, porezni klin pokazuje trend smanjenja, jer se pri toj razini plaće doseže gornja granica za obračun doprinosa; porezni klin se tako smanjuje prema razini od $50 \%$ za najviše bruto plaće koje prikazuje Grafikon 3.

\section{GRAFIKON 3.}

Neto prosječni porezni klin i neto prosječna porezna stopa za samce bez djece (Austrija, 2013.), u \%

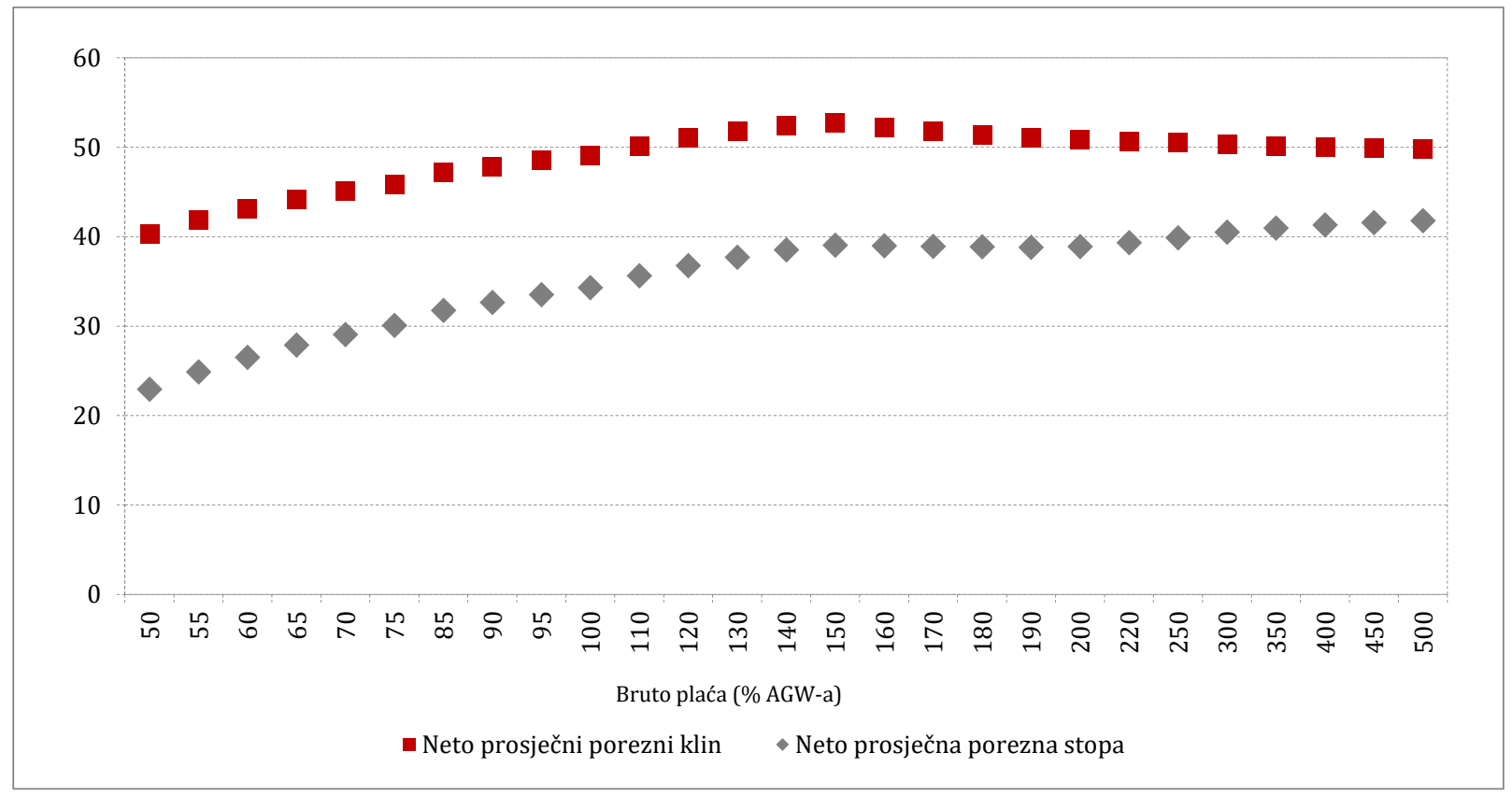

Izvor: autorovi izračuni.

Kod neto prosječnog poreznog klina za parove (Grafikon 4) mogu se uočiti intervali na kojima klin "stagnira", odnosno ne mijenja se unatoč povećanju plaće jednog od supružnika. Prvi takav interval vidljiv je za parove u kojima jedan supružnik ostvaruje 100\% AGW-a, a plaća drugog supružnika 
raste od 0 do $50 \% \mathrm{AGW}$-a; drugi interval počinje s parom u kojemu supružnici ostvaruju bruto plaće od $140 \%$ i $120 \%$ AGW-a, a taj interval se širi do kraja promatranog raspona.

\section{GRAFIKON 4.}

Neto prosječni porezni klin i neto prosječna porezna stopa za parove s dvoje djece (Austrija, 2013.), u \%

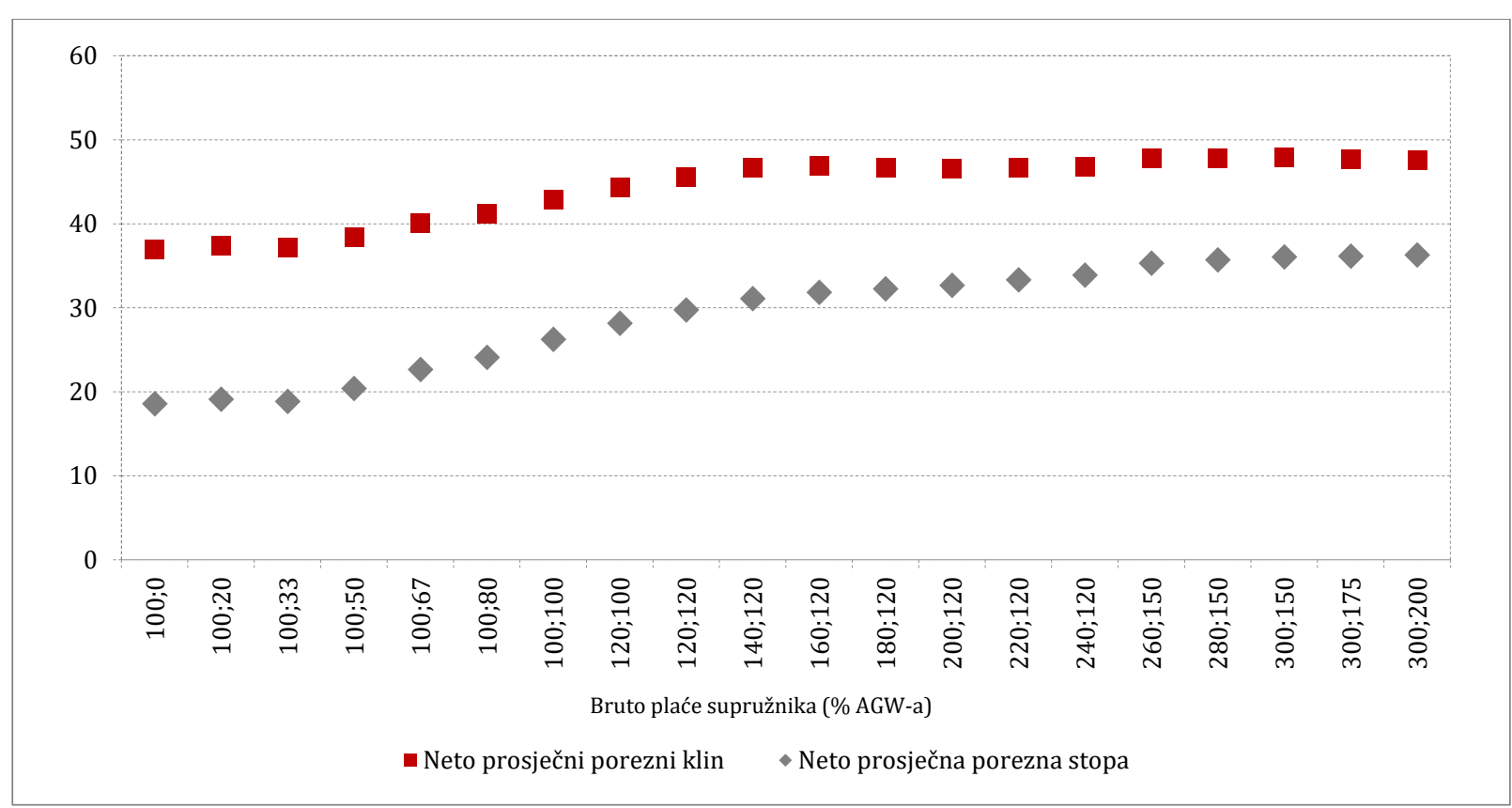

Izvor: autorovi izračuni.

\subsection{GRČKA}

\subsubsection{OSNOVNI ELEMENTI OPOREZIVANJA RADA U GRČKOJ}

U Grčkoj postoje tri vrste doprinosa za socijalno osiguranje, a sve ih plaćaju i posloprimci i poslodavci (Tablica 12). Ukupna stopa za poslodavce je relativno visoka i iznosi 27,46\%. Najviša godišnja osnovica za obračun doprinosa iznosi 66.562 eura.

\section{TABLICA 12.}

Stope doprinosa za socijalno osiguranje (Grčka, 2013.)

\begin{tabular}{lcc} 
Naziv doprinosa & $\begin{array}{c}\text { Doprinos zaposlenika } \\
\text { (\% bruto plaće) }\end{array}$ & $\begin{array}{c}\text { Doprinos poslodavca } \\
\text { (\% bruto plaće) }\end{array}$ \\
\hline Socijalno osiguranje (IKA) & 9,22 & 18,43 \\
\hline Socijalno osiguranje (ETEAM) & 3 & 3 \\
\hline Ostali fondovi za osiguranje & 4,28 & 6,03 \\
\hline Ukupno & 16,50 & 27,46 \\
\hline
\end{tabular}

Napomene: IKA i ETEAM su nazivi fondova koji upravljaju doprinosima za socijalno osiguranje. Izvor: OECD (2014.).

U izračunu osnovice poreza na dohodak kao odbitak se priznaju jedino doprinosi za socijalno osiguranje. Razrede i stope poreza na dohodak prikazuje Tablica 13. 
TABLICA 13.

Razredi i stope poreza na dohodak (Grčka, 2013.)

Porezni razred (u eurima)

Porezna stopa (u \%)

\begin{tabular}{cc}
\hline$[0,25.000]$ & 22 \\
\hline$\langle 25.000,42.000]$ & 32 \\
\hline$\langle 42.000,+\infty\rangle$ & 42 \\
\hline
\end{tabular}

Izvor: OECD (2014.).

U Grčkoj postoji još jedan posebni porez, a naziva se "doprinos za solidarnost". Obračunava se kao postotak bruto plaće umanjene za doprinose zaposlenika. Stope prikazuje Tablica 14.

TABLICA 14.

Stope doprinosa za solidarnost (Grčka, 2013.)

\begin{tabular}{cc}
$\begin{array}{c}\text { Bruto dohodak umanjen za doprinose } \\
\text { (u eurima) }\end{array}$ & $\begin{array}{c}\text { Doprinos za solidarnost } \\
\text { (u \%) }\end{array}$ \\
\hline$[0,12.000]$ & 0 \\
\hline$\langle 12.000,20.000]$ & 1 \\
\hline$\langle 20.000,50.000\rangle$ & 2 \\
\hline$\langle 100.000,100.000\rangle$ & 3 \\
\hline
\end{tabular}

Izvor: OECD (2014.).

U Grčkoj postoji samo jedna vrsta umanjenja poreza i računa se na sljedeći način: neka je $x$ bruto plaća. Ako je $x \leq 21.000$ eura, umanjenje poreza iznosi 2.100 eura. Ako je $x>21.000$, tada se za svakih 1.000 eura umanjenje poreza od 2.100 eura smanjuje za 100 eura. Dakle, ako bruto plaća iznosi 30.000 eura, umanjenje poreza jednako je 1.200 eura.

Porez na platnu listu ne postoji. Također ne postoje ni novčane naknade za obitelj. Međutim, postoji jedna posebnost koju se iz jednostavnih razloga svrstava u kategoriju novčanih naknada. Ako posloprimac ima supružnika, poslodavac je dužan standardnu bruto plaću uvećati za $10 \%$, a za svako dijete dodatno za 5\%. Primjerice, ako posloprimac ima supružnika i dvoje djece, njegova će bruto plaća biti uvećana za $20 \%$.

\subsubsection{POKAZATELJI POREZNOG OPTEREĆENJA}

Tablica 15 prikazuje pokazatelje poreznog opterećenja u Grčkoj. Porezni klin samohranog roditelja s dvoje djece (A-67-2C) viši je od poreznog klina za samca bez djece s istom plaćom (A-67-NC). Slično tome, porezni klin za 2A-100/33-2C (s dvoje djece) viši je nego za 2A-100/33-NC (bez djece). Ti su nalazi u suprotnosti s rezultatima za Hrvatsku i Austriju, gdje jedinice s djecom imaju niže porezno opterećenje od jedinica s istim dohotkom bez djece. Za objašnjenje je potrebno prisjetiti se specifičnog poslodavčevog dodatka za djecu u Grčkoj, koji ulazi u bruto plaću, pa se njegov utjecaj ne može uočiti u ovoj analizi koja kreće od istih početnih bruto plaća. 
TABLICA 15.

Pokazatelji poreznog opterećenja za osnovne hipotetske jedinice (Grčka, 2013.), u \%

\begin{tabular}{|c|c|c|c|c|c|c|c|c|}
\hline & $\begin{array}{c}\text { A-67- } \\
\text { NC }\end{array}$ & $\begin{array}{c}\text { A-100- } \\
\text { NC }\end{array}$ & $\begin{array}{c}\text { A-167- } \\
\text { NC }\end{array}$ & $\begin{array}{c}\text { A-67- } \\
2 C\end{array}$ & $\begin{array}{c}2 A- \\
100 / 0 \\
-2 C\end{array}$ & $\begin{array}{c}2 A- \\
100 / 33 \\
-2 C\end{array}$ & $\begin{array}{c}2 A- \\
100 / 67 \\
-2 C\end{array}$ & $\begin{array}{c}2 A- \\
100 / 33 \\
-N C\end{array}$ \\
\hline $\begin{array}{l}\text { Prosječna stopa poreza na } \\
\text { dohodak }\end{array}$ & 3,08 & 9,01 & 18,78 & 5,31 & 12,76 & 9,57 & 10,24 & 7,79 \\
\hline $\begin{array}{l}\text { Prosječna stopa doprinosa } \\
\text { posloprimca }\end{array}$ & 16,5 & 16,5 & 16,5 & 16,5 & 16,5 & 16,5 & 16,5 & 16,5 \\
\hline Neto prosječna porezna stopa & 19,58 & 25,51 & 35,28 & 21,81 & 29,26 & 26,07 & 26,74 & 24,29 \\
\hline Neto prosječni porezni klin & 36,91 & 41,56 & 49,22 & 38,65 & 44,5 & 42 & 42,52 & 40,6 \\
\hline
\end{tabular}

Izvor: OECD (2014.) i autorovi izračuni.

Grafikoni 5 i 6 prikazuju kretanje neto prosječnog poreznog klina i neto prosječne porezne stope u širokom rasponu bruto plaća, za dodatne skupove hipotetskih samaca i parova s dvoje djece. Kod samaca (Grafikon 5) porezni klin za relativno visoke bruto plaće prelazi 55\%, ali nakon 300\% AGWa se smanjuje prema 50\%, zahvaljujući najvišoj osnovici za obračun doprinosa.

Kod parova (Grafikon 6) je zanimljivo uočiti blagi regresivni trend neto prosječnog poreznog klina i neto prosječne porezne stope, koji padaju u intervalu od para s bruto plaćama od 100 i 0\% AGWa prema paru s bruto plaćama od 100 i 50\% AGW-a.

\section{GRAFIKON 5.}

Neto prosječni porezni klin i neto prosječna porezna stopa za samce bez djece (Grčka, 2013.), u \%

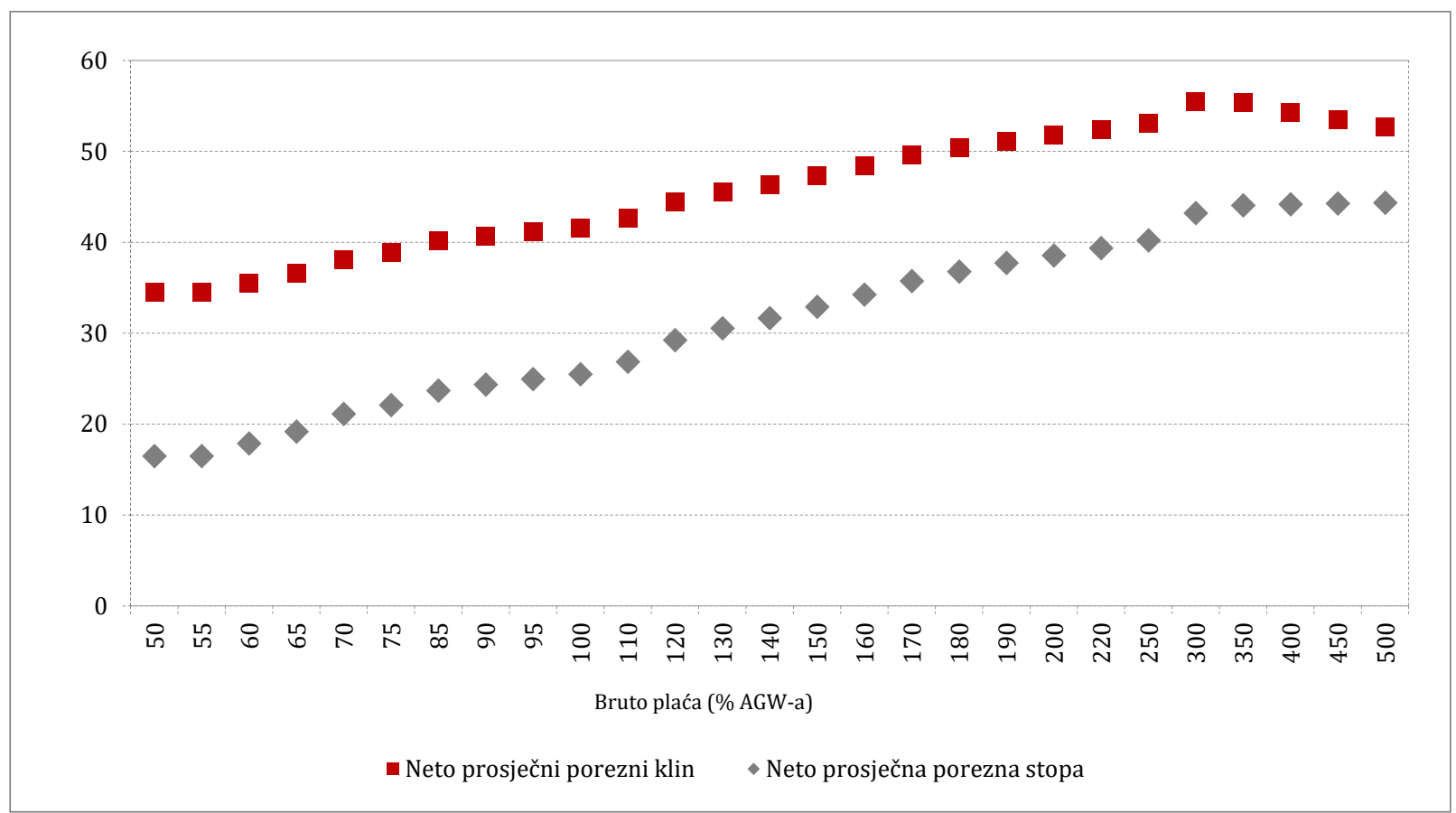

Izvor: autorovi izračuni. 
GRAFIKON 6.

Neto prosječni porezni klin i neto prosječna porezna stopa za parove s dvoje djece (Grčka, 2013.), u \%

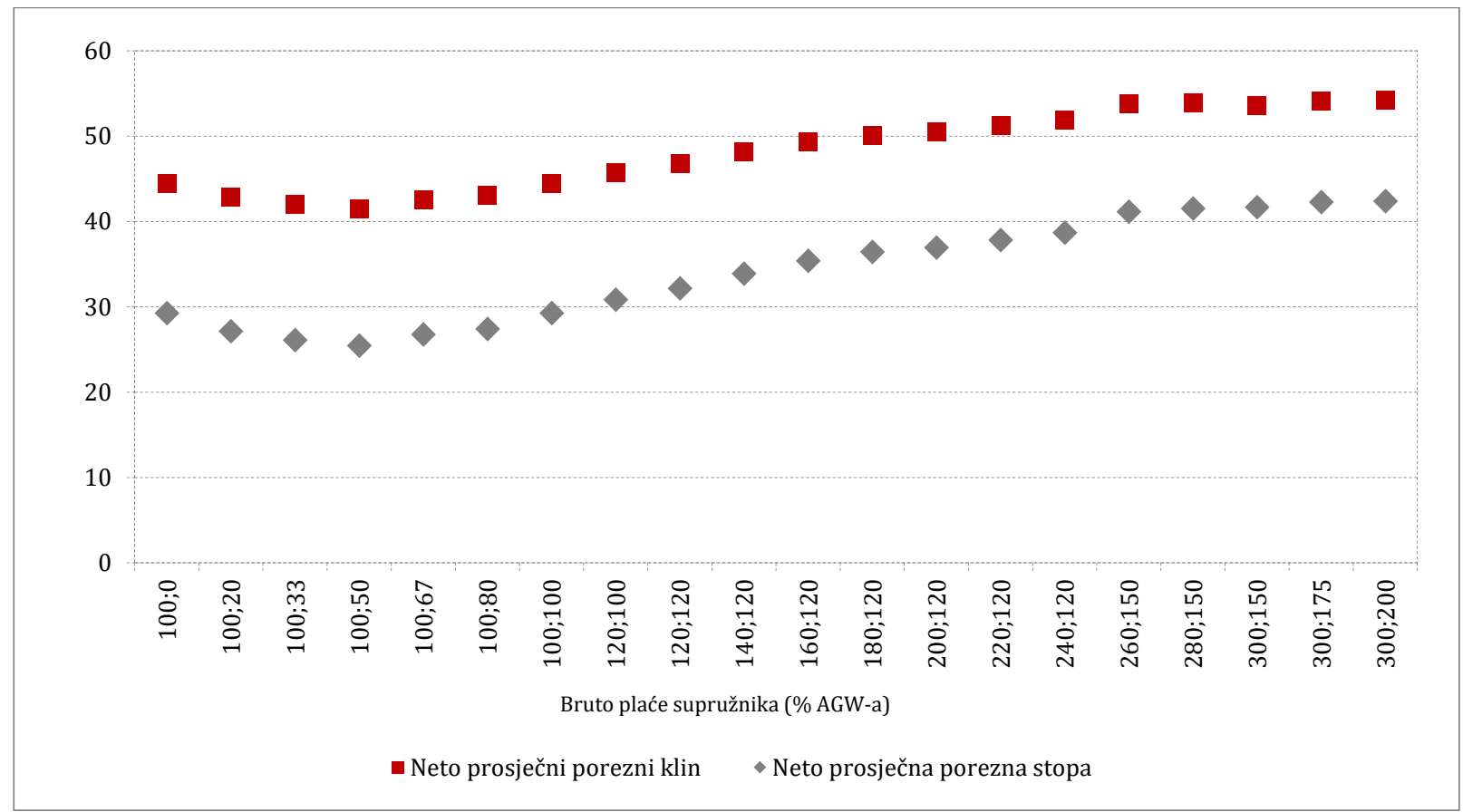

Izvor: autorovi izračuni.

\subsection{MAĐARSKA}

\subsubsection{OSNOVNI ELEMENTI OPOREZIVANJA RADA U MAĐARSKOJ}

Mađarska ima tri vrste doprinosa za socijalno osiguranje, a plaćaju ih i posloprimci i poslodavci.

Također kao u Grčkoj, doprinosi poslodavca su relativno visoki i ukupno iznose $27 \%$ bruto plaće.

Detaljne stope prikazane su u tablici 16.

\section{TABLICA 16.}

Stope doprinosa za socijalno osiguranje (Mađarska, 2013.)

\begin{tabular}{lcc} 
Naziv doprinosa & $\begin{array}{c}\text { Doprinos zaposlenika } \\
\text { (\% bruto plaće) }\end{array}$ & $\begin{array}{c}\text { Doprinos poslodavca } \\
\text { (\% bruto plaće) }\end{array}$ \\
\hline Mirovinsko osiguranje & 10,0 & 24,0 \\
\hline Zdravstveno osiguranje & 7,0 & 2,0 \\
\hline Osiguranje od nezaposlenosti & 1,5 & 1,0 \\
\hline Ukupno & 18,5 & 27,0 \\
\hline
\end{tabular}

Izvor: OECD (2014.).

U sustavu poreza na dohodak priznaju se odbici za djecu: za svako dijete po 206 eura mjesečno. Postoji samo jedna stopa, a iznosi $16 \%$. Ne postoje umanjenja poreza.

Porez na platnu listu iznosi 1,5\% bruto plaće.

Novčani transferi iznose 98 eura mjesečno za samca s dvoje djece te 88 eura mjesečno za par s dvoje djece. 


\subsubsection{POKAZATELJI POREZNOG OPTEREĆENJA}

Tablica 17 prikazuje pokazatelje poreznog opterećenja u Mađarskoj. Porezni klin samohranog roditelja s dvoje djece (A-67-2C) niži je za čak 24 postotna boda nego kod samca bez djece s istom plaćom (A-67-NC). Razlika od 11 postotnih bodova utvrđuje se usporedbom hipotetskih parova 2A100/33-2C (s dvoje djece) i 2A-100/33-NC (bez djece). Dakle, odbici u sustavu poreza na dohodak i naknade za djecu imaju značajan učinak na porezno opterećenje u Mađarskoj.

TABLICA 17.

Pokazatelji poreznog opterećenja za osnovne hipotetske jedinice (Mađarska, 2013.), u \%

\begin{tabular}{lcccccccc} 
& $\begin{array}{c}\text { A-67- } \\
\text { NC }\end{array}$ & $\begin{array}{c}\mathbf{A - 1 0 0 -} \\
\mathbf{N C}\end{array}$ & $\begin{array}{c}\mathbf{A - 1 6 7 -} \\
\mathbf{N C}\end{array}$ & $\begin{array}{c}\mathbf{A - 6 7 -} \\
\mathbf{2 C}\end{array}$ & $\begin{array}{c}\mathbf{2 A -} \\
\mathbf{1 0 0 / 0} \\
\mathbf{- 2 C}\end{array}$ & $\begin{array}{c}\mathbf{2 A -} \\
\mathbf{1 0 0 / 3 3} \\
\mathbf{- 2 C}\end{array}$ & $\begin{array}{c}\mathbf{2 A -} \\
\mathbf{1 0 0 / 6 7} \\
\mathbf{- 2 C}\end{array}$ & $\begin{array}{c}\mathbf{1 0 0 / 3 3} \\
\mathbf{- N C}\end{array}$ \\
\hline $\begin{array}{l}\text { Prosječna stopa poreza na } \\
\text { dohodak }\end{array}$ & 16,00 & 16,00 & 16,00 & 3,65 & 7,77 & 9,82 & 11,06 & 16,00 \\
\hline $\begin{array}{l}\text { Prosječna stopa doprinosa } \\
\text { posloprimca }\end{array}$ & 18,50 & 18,50 & 18,50 & 18,50 & 18,50 & 18,50 & 18,50 & 18,50 \\
\hline Neto prosječna porezna stopa & 34,50 & 34,50 & 34,50 & 3,87 & 15,31 & 20,11 & 22,99 & 34,50 \\
\hline Neto prosječni porezni klin & 49,03 & 49,03 & 49,03 & 25,19 & 34,10 & 37,83 & 40,07 & 49,03 \\
\hline
\end{tabular}

Izvor: OECD (2014.) i autorovi izračuni.

U analizi sustava može se primijetiti kako za samce bez djece nema poreznih olakšica, umanjenja poreza ni novčanih transfera, a primjenjuje se samo jedna stopa za obračun poreza na dohodak i jedna stopa za doprinose zaposlenika i poslodavca. Zbog toga su porezni klin i omjer plaćenog poreza i bruto plaće jednaki za sve bruto plaće samaca bez djece (Tablica 17 i Grafikon 7). Dakle, porezni sustav u Mađarskoj za samce bez djece djeluje proporcionalno.

(14) S druge strane, za parove s djecom sustav je progresivan i to zahvaljujući osobnom odbitku za uzdržavanu djecu i univerzalnoj naknadi za djecu (Grafikon 8).

\section{GRAFIKON 7.}

Neto prosječni porezni klin i neto prosječna porezna stopa za samce bez djece (Mađarska, 2013.), u \%

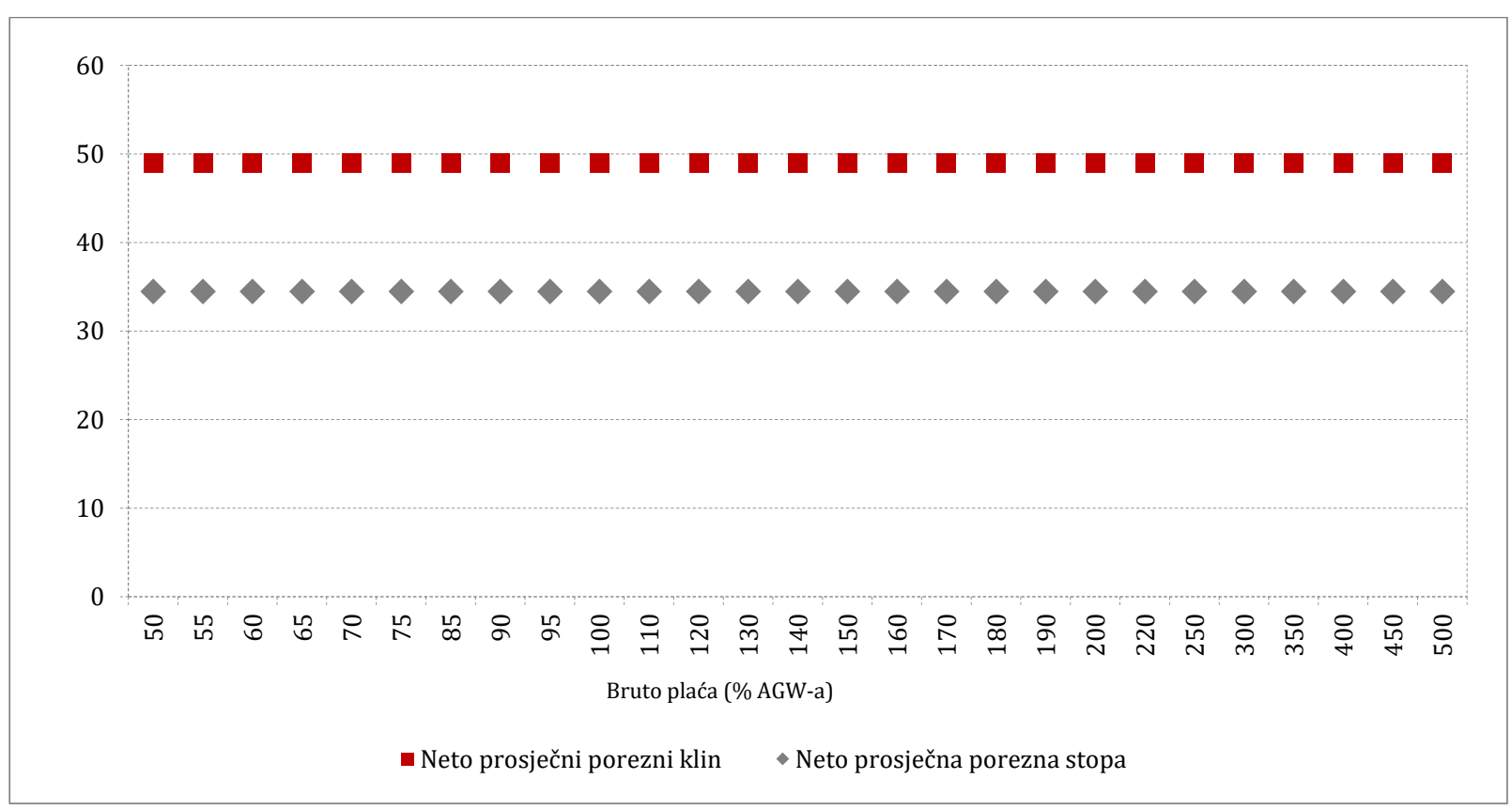

Izvor: autorovi izračuni. 
GRAFIKON 8.

Neto prosječni porezni klin i neto prosječna porezna stopa za parove s dvoje djece (Mađarska, 2013.), $u \%$

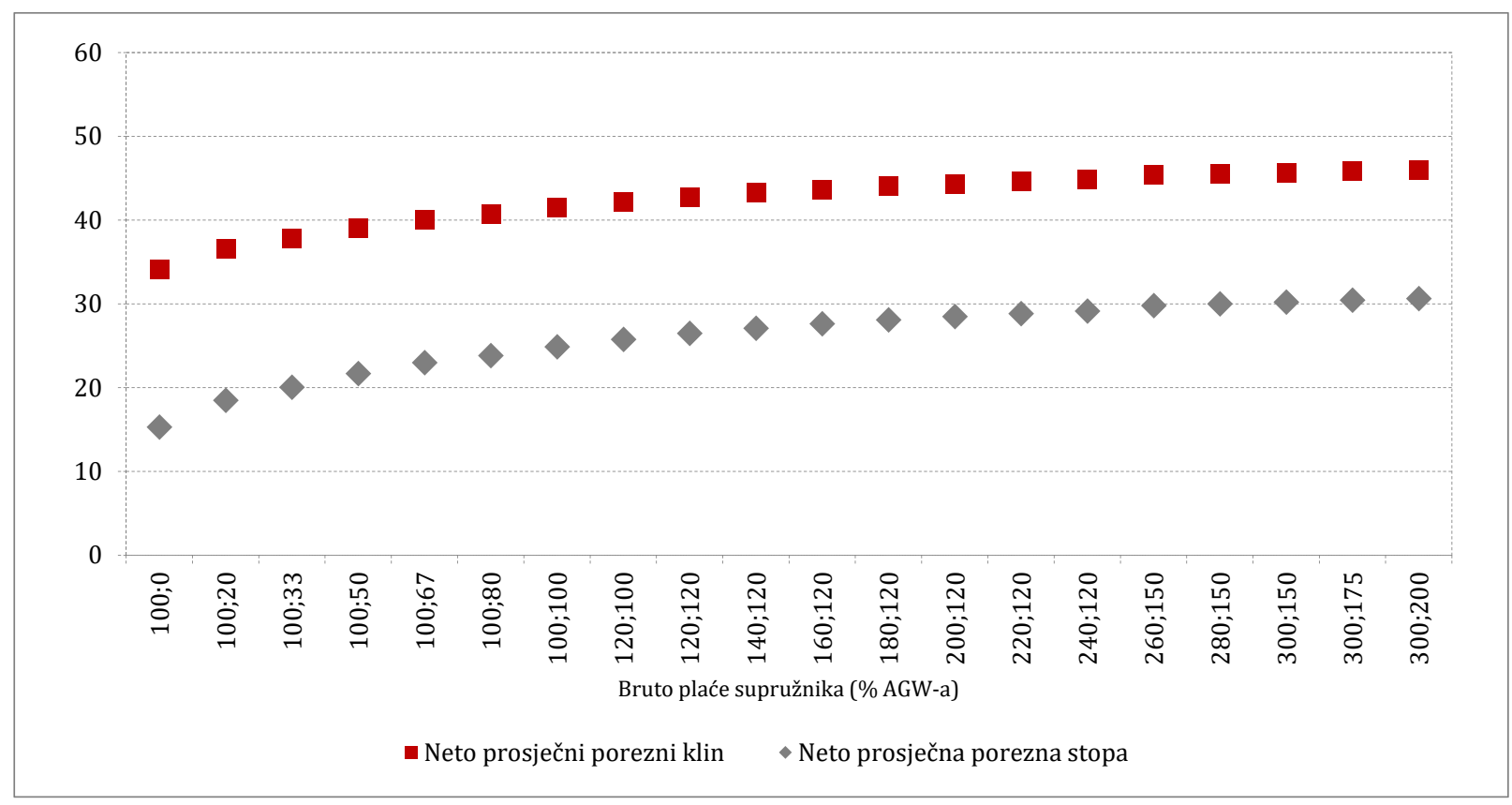

Izvor: autorovi izračuni.

\subsection{POLJSKA}

\subsubsection{OSNOVNI ELEMENTI OPOREZIVANJA RADA U POLJSKOJ}

Tablica 18. prikazuje osnovne informacije o stopama doprinosa za socijalno osiguranje u Poljskoj. Međutim, obračun doprinosa je prilično složen, odnosno ne slijedi jednostavni obrazac kao u većini ostalih zemalja. Za način izračuna, vidjeti OECD (2014.). Za mirovinske doprinose i doprinos za nezaposlenost vrijedi najviša osnovica od 26.555 eura.

\section{TABLICA 18.}

Stope doprinosa za socijalno osiguranje (Poljska, 2013.)

\begin{tabular}{lcc} 
Naziv doprinosa & $\begin{array}{c}\text { Doprinos posloprimca } \\
\text { (\% bruto plaće) }\end{array}$ & $\begin{array}{c}\text { Doprinos poslodavca } \\
\text { (\% bruto plaće) }\end{array}$ \\
\hline Mirovinsko osiguranje ZUS & 6,11 & 6,11 \\
\hline Mirovinsko osiguranje ZUS II & 2,25 & 2,25 \\
\hline Mirovinsko osiguranje OPF & 1,40 & 1,40 \\
\hline Doprinos za nezaposlenost & 1,50 & 6,50 \\
\hline Osiguranje od bolesti & 2,45 & 4,17 \\
\hline Zdravstveno osiguranje & 9,00 & -
\end{tabular}

aZUS i ZUS II su nazivi institucija koje upravljaju mirovinskim fondovima. OPF je otvoreni mirovinski fond. Izvor: OECD (2014.).

Poljska primjenjuje dva odbitka u sustavu poreza na dohodak. Osnovna olakšica za posao je fiksna i iznosi 318 eura za svakog radnika, dok je druga olakšica jednaka dijelu doprinosa posloprimca i izračunava se posebnom formulom. 
Za obračun poreza na dohodak u Poljskoj primjenjuju se dvije stope u dva razreda (Tablica 19). Nakon primjene poreznih stopa, posloprimci mogu koristiti tri vrste umanjenja poreza. Osnovno umanjenje poreza iznosi 133 eura godišnje ili 265 eura godišnje za samca s djecom. Umanjenje poreza za djecu iznosi 133 eura godišnje za svako dijete uz uvjet da jedan roditelj prima bruto plaću manju od 26.700 eura godišnje, a drugi manju od 13.350 eura godišnje. Doprinos za zdravstveno osiguranje priznaje se gotovo u cijelosti kao umanjenje poreza.

Nema poreza na platnu listu. Također se ne primjenjuju novčane naknade za obitelj.

TABLICA 19.

Razredi i stope poreza na dohodak (Poljska, 2013.)

Porezni razred u PLN

Porezna stopa

\begin{tabular}{cc}
\hline$[0,20.390]$ & $18 \%$ \\
\hline$\langle 20.390+\infty\rangle$ & $3.538+32 \%$ \\
\hline
\end{tabular}

Izvor: OECD (2014.).

\subsubsection{POKAZATELJI POREZNOG OPTEREĆENJA}

Tablica 20 prikazuje pokazatelje poreznog opterećenja u Poljskoj. Može se primijetiti da je prosječna stopa poreza na dohodak prilično niska i relativno sporo raste s dohotkom. Porezni klin samohranog roditelja s dvoje djece (A-67-2C) niži je za 5 postotnih bodova nego kod samca bez djece s istom plaćom (A-67-NC). Usporedbom hipotetskih parova 2A-100/33-2C (s dvoje djece) i 2A-100/33-NC (bez djece) uočava se razlika od 3,5 postotna boda.

TABLICA 20.

Pokazatelji poreznog opterećenja za osnovne hipotetske jedinice (Poljska, 2013.), u \%

\begin{tabular}{|c|c|c|c|c|c|c|c|c|}
\hline & $\begin{array}{l}\text { A-67- } \\
\text { NC }\end{array}$ & $\begin{array}{l}\text { A-100- } \\
\text { NC }\end{array}$ & $\begin{array}{l}\text { A-167- } \\
\text { NC }\end{array}$ & $\begin{array}{l}\text { A-67- } \\
2 C\end{array}$ & $\begin{array}{l}2 A- \\
100 / 0 \\
-2 C\end{array}$ & $\begin{array}{c}2 A- \\
100 / 33 \\
-2 C\end{array}$ & $\begin{array}{c}2 A- \\
100 / 67 \\
-2 C\end{array}$ & $\begin{array}{c}2 A- \\
100 / 33 \\
-N C\end{array}$ \\
\hline $\begin{array}{l}\text { Prosječna stopa poreza na } \\
\text { dohodak }\end{array}$ & 5,96 & 6,92 & 7,69 & 0,00 & 0,22 & 1,94 & 3,32 & 5,96 \\
\hline $\begin{array}{l}\text { Prosječna stopa doprinosa } \\
\text { posloprimca }\end{array}$ & 17,83 & 17,83 & 17,83 & 17,83 & 17,83 & 17,83 & 17,83 & 17,83 \\
\hline Neto prosječna porezna stopa & 23,79 & 24,75 & 25,52 & 17,83 & 18,04 & 19,76 & 21,14 & 23,79 \\
\hline Neto prosječni porezni klin & 34,74 & 35,56 & 36,22 & 29,63 & 29,82 & 31,29 & 32,48 & 34,74 \\
\hline
\end{tabular}

Izvor: OECD (2014.) i autorovi izračuni.

Sustav oporezivanja rada u Poljskoj je progresivan za samce i parove s djecom, ali promjene neto prosječnog poreznog klina i porezne stope, gledano na širokom rasponu bruto plaća, relativno su blage (grafikoni 9 i 10). 
GRAFIKON 9.

Neto prosječni porezni klin i neto prosječna porezna stopa za samce bez djece (Poljska, 2013.), u \%

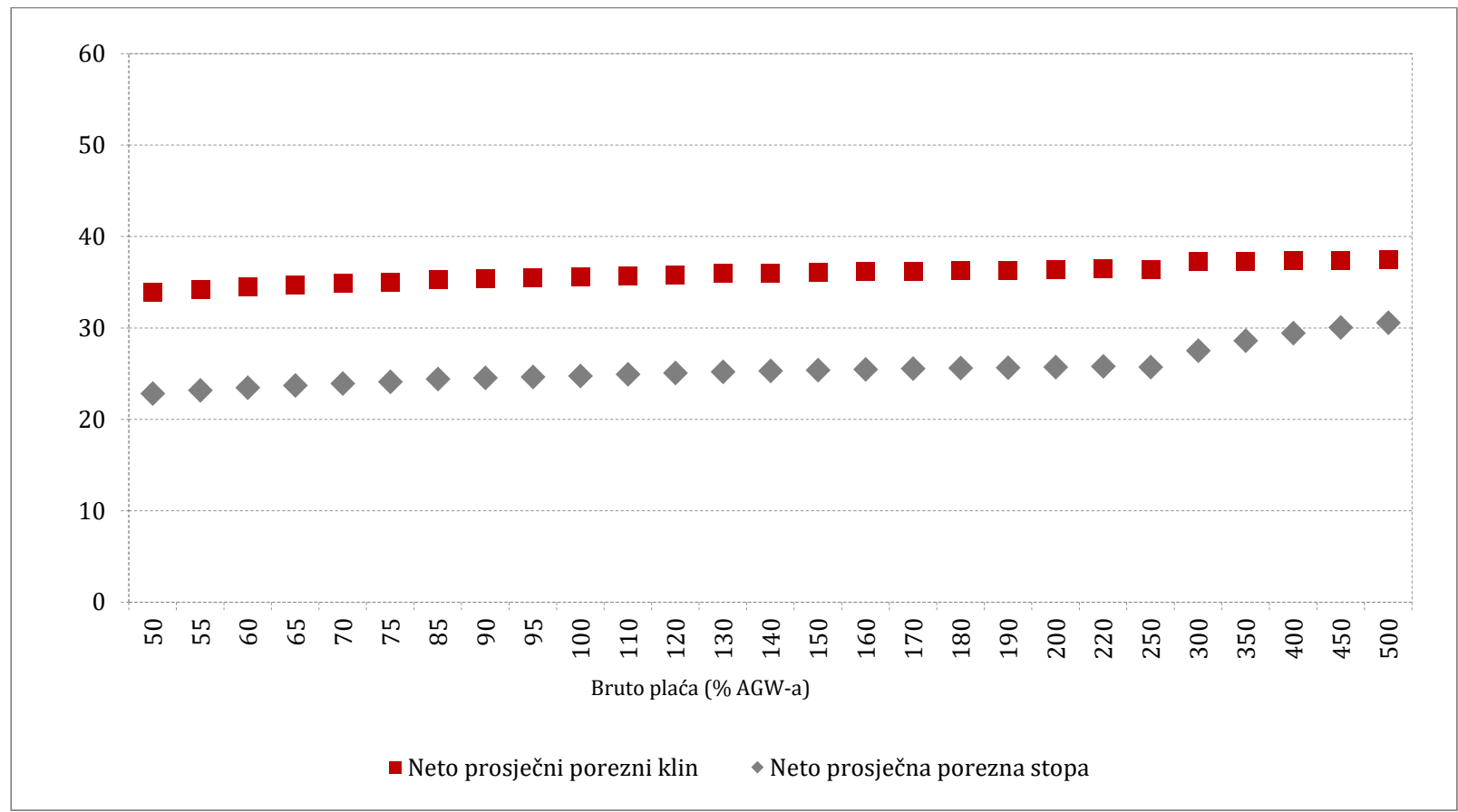

Izvor: autorovi izračuni.

\section{GRAFIKON 10.}

Neto prosječni porezni klin i neto prosječna porezna stopa za parove s dvoje djece (Poljska, 2013.), u \%

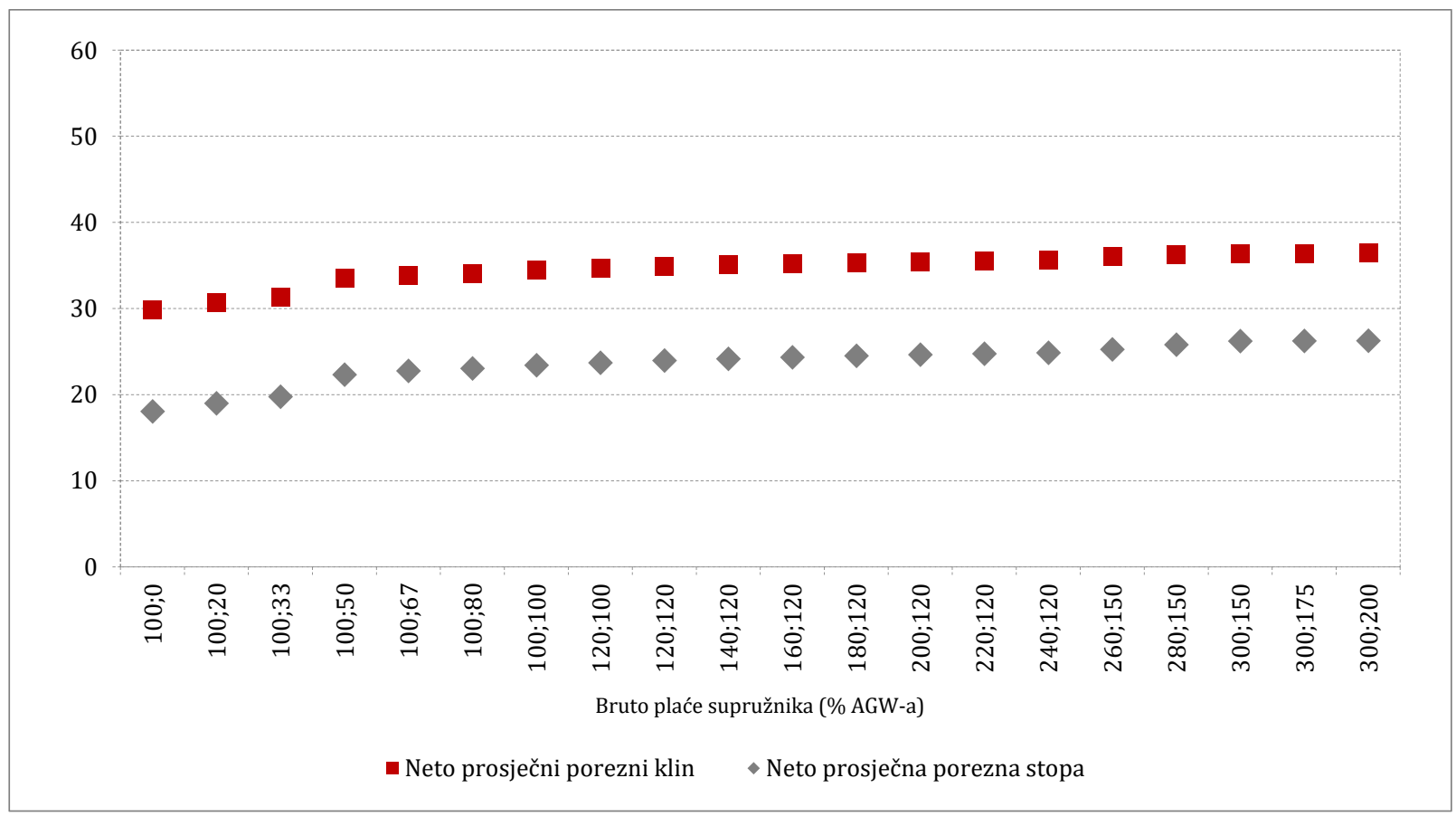

Izvor: autorovi izračuni. 


\section{USPOREDNI REZULTATI}

U ovome dijelu rada daje se usporedna analiza rezultata dobivenih u trećem poglavlju. Kako bi se zaključilo koja država najviše oporezuje građane, ponovno se promatraju hipotetski parovi s dvoje djece i samci bez djece, a uspoređuje se neto prosječni porezni klin.

\section{GRAFIKON 11.}

Neto prosječni porezni klin za samce (2013.), u \%

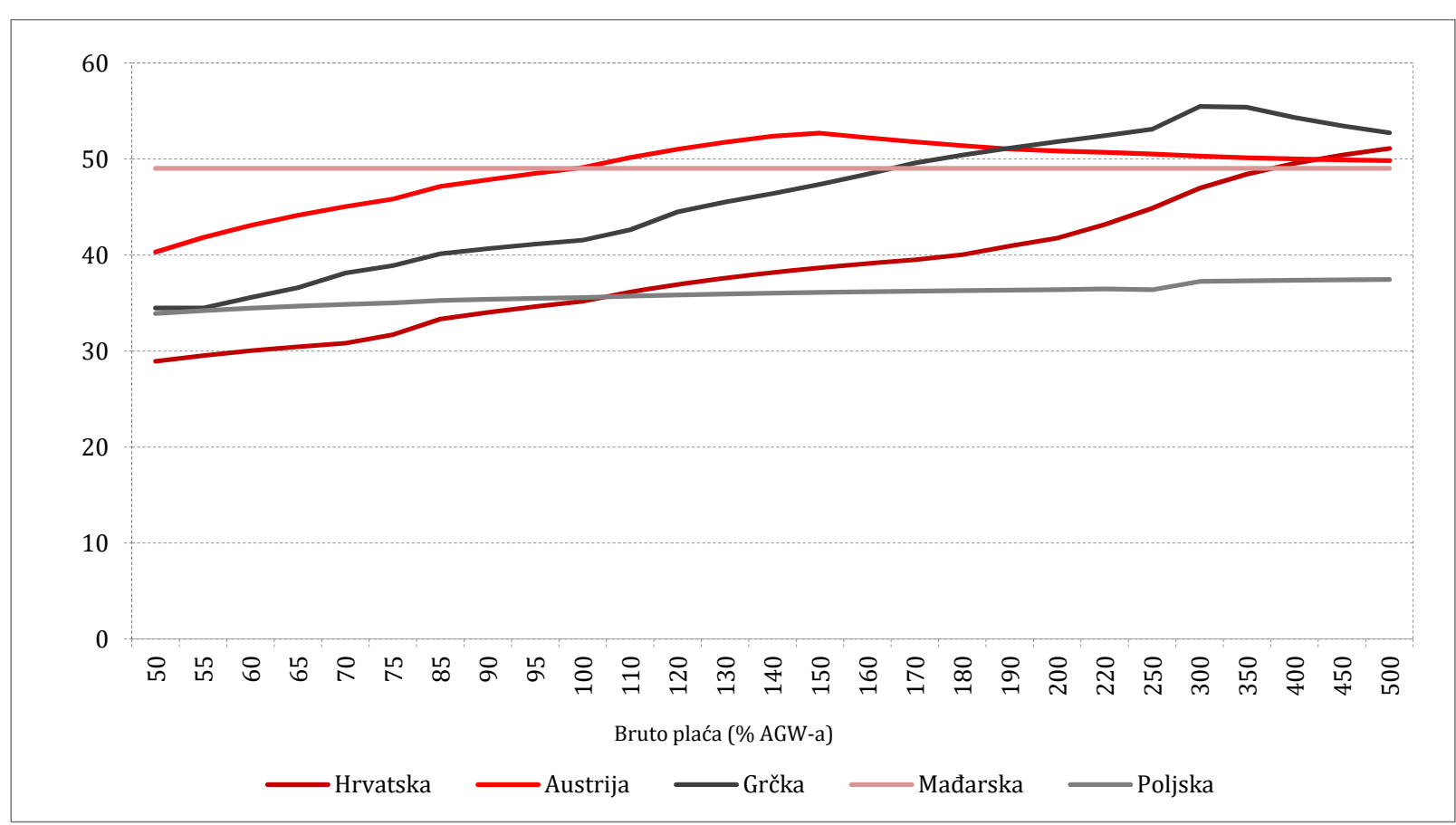

Izvor: autorovi izračuni.

Kod samaca, za bruto plaće ispod 100\% AGW-a porezni klin najniži je u Hrvatskoj, a slijede Poljska i Grčka (Grafikon 11). U intervalu iznad bruto plaće od 100\% AGW-a, Poljska uvjerljivo ima najniži porezni klin, dok se krivulje Mađarske, Austrije i Grčke "isprepleću" na ovom intervalu. Krivulja poreznog klina za Hrvatsku vrlo brzo raste u intervalu od 180\% do 400\% AGW-a i za najviše plaće doseže spomenute tri zemlje.

Grčka prednjači u poreznom klinu za sve razine plaća kod parova s dvoje djece (Grafikon 12). Iako Mađarska i Austrija imaju veoma različite sustave oporezivanja dohotka od rada, može se primijetiti kako su mađarski i austrijski porezni klin vrlo slični za sve razine bruto plaće. Klinovi Hrvatske i Poljske su najniži među promatranim zemljama, a kao i u slučaju samaca, porezni klin je na početnom intervalu viši u Poljskoj, da bi u određenoj točki hrvatski klin nadmašio poljski. Uspoređujući grafikone 12 i 11, može se lako zaključiti da se međuodnos krivulja poreznog klina prilično razlikuje za samce i parove s djecom, a razlog za to je primjena bitno različitih poreznih olakšica i novčanih naknada za obitelji s djecom. 
GRAFIKON 12.

Neto prosječni porezni klin za parove s dvoje djece (2013.), u \%

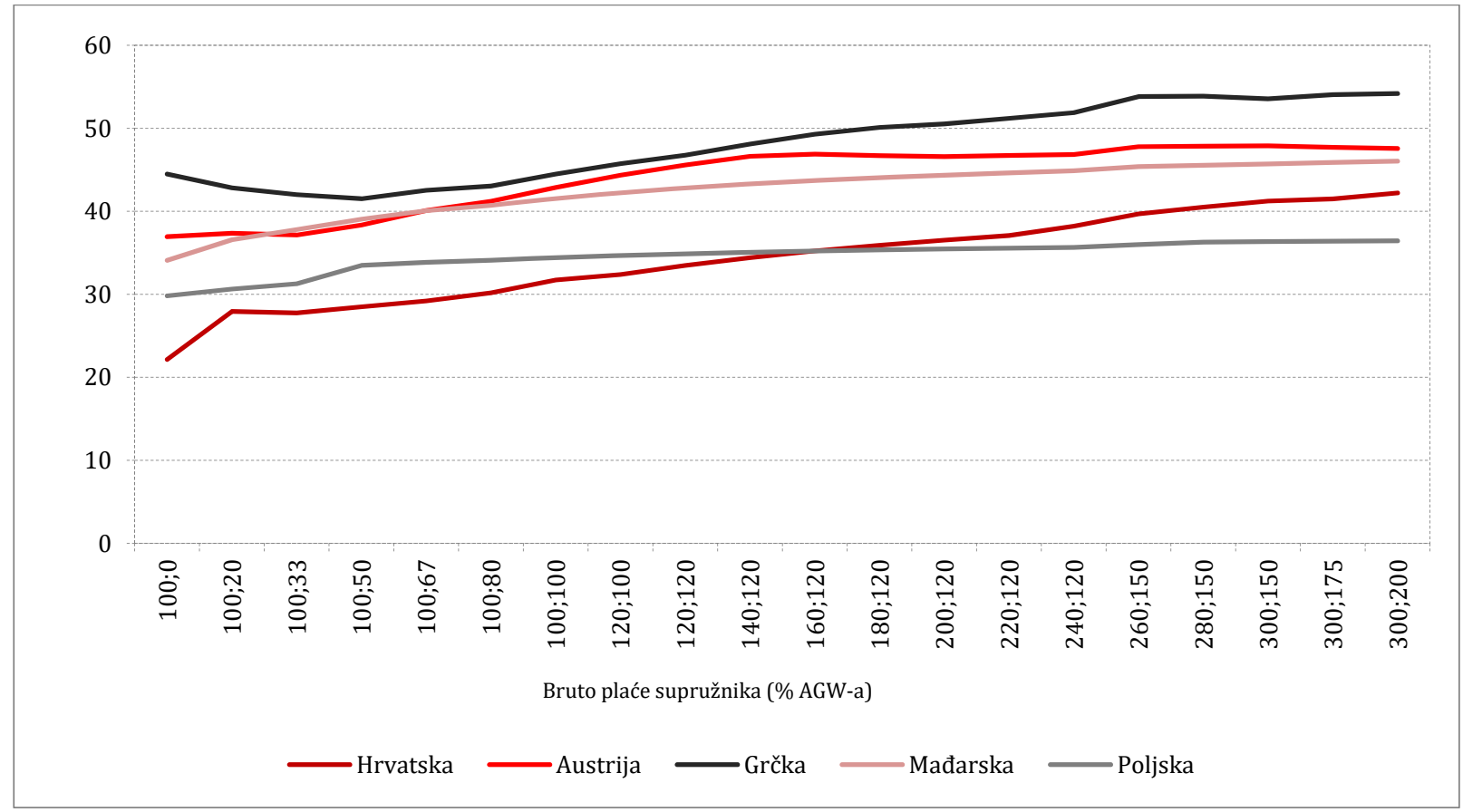

Izvor: autorovi izračuni.

\section{ZAKLJUČAK}

Cilj ovog rada bio je usporediti prosječno porezno opterećenje u Hrvatskoj, Austriji, Grčkoj, Mađarskoj i Poljskoj. Korišteni su podaci i metodologija OECD-a, prikazani u publikaciji Taxing Wages. Međutim, osim za osam hipotetskih obitelji koje definira OECD, napravljeni su izračuni pokazatelja i za niz drugih hipotetskih jedinica u velikom rasponu ostvarenih bruto plaća. Potonje se čini kako bi se stekao uvid u porezno opterećenje pri višim dohocima. U spomenutim izračunima korišten je mikrosimulacijski model za hipotetske jedinice u svih pet zemalja, koji je autor razvio za potrebe ovog istraživanja.

Iako su promatrane zemlje geografski relativno bliske i sve pripadaju EU, može se uočiti prilična različitost u pogledu sustava oporezivanja dohotka od rada. Svaka zemlja ima određene specifičnosti kojima odudara od ostalih zemalja. Primjerice, Poljska ima relativno složen način obračuna doprinosa za socijalno osiguranje; Mađarska ima samo jednu stopu u sustavu poreza na dohodak; Grčka nema klasične naknade za djecu, već poslodavci uvećavaju bruto plaću posloprimaca s djecom za određeni postotak; Hrvatska nema umanjenja porezne obveze, a ima doplatak za djecu koji je naknada s provjerom dohotka, itd.

Unatoč razlikama u sustavima oporezivanja, neke zemlje imaju slične obrasce i razine neto prosječnog poreznog klina za različite razine plaća (primjerice Mađarska i Austrija kod parova s djecom). Usporedbom hipotetskih jedinica sa i bez djece moglo se vidjeti kako je relativna izdašnost poreznih olakšica i naknada za djecu različita među zemljama.

Hrvatska se pokazala kao zemlja s najnižim neto prosječnim poreznih klinom samaca za niže plaće, a za bruto plaće samaca iznad prosjeka najniži je klin u Poljskoj. Međutim, treba spomenuti kako i 
Poljska i Hrvatska imaju dodatne doprinose za socijalno osiguranje koji, sukladno korištenoj metodologiji, ne ulaze u porezno opterećenje (vidjeti Urban, 2016.).

Analiza na temelju velikog raspona dohodaka baca bolje svjetlo na obrazac poreznog klina u Hrvatskoj: iako je relativno nizak za malene bruto plaće, on strmo raste i kod visokih plaća doseže razinu zabilježenu kod ostalih zemalja (Austrije, Mađarske i Grčke). 


\section{REFERENCE}

1. CBS, 2015. DZS website. [online] Dostupno na: <http://www.dzs.hr/>.

2. KPMG, 2014. 2014 KPMG International Annual Review. [online] Dostupno na: <http://www.kpmg.com/TW/zh/Documents/2014/international-annual-review-2014.pdf>.

3. OECD, 2014. Taxing Wages 2014. Paris: OECD.

4. OECD, 2015. Non-tax compulsory payments as an additional burden on labour income. [online] Dostupno na: <http://www.oecd.org/tax/tax-policy/Non-tax-compuslory-payments_2014.pdf>.

5. Urban, I., 2016. Tax wedge on labour income in Croatia and the European Union. Financial Theory and Practice, 40(2), str. 157-168. doi: 10.3326/fintp.40.2.1

6. Zakon o doplatku za djecu, NN 94/01, 138/06, 107/07, 37/08, 61/11, 112/12, 82/15. [online] Dostupno na: <http://www.zakon.hr/z/475/zakon-o-doplatku-za-djecu>.

7. Zakon o doprinosima, NN 84/08., 152/08., 94/09., 18/11., 22/12., 144/12., 148/13., 41/14., 143/14. [online] Dostupno na: <http://www.zakon.hr/z/365/Zakon-o-doprinosima>.

8. Zakon o porezu na dohodak, NN 177/04., 73/08., 80/10., 114/11., 22/12., 144/12., 43/13., 120/13., 125/13., 148/13., 83/14., 143/14. [online] Dostupno na: <http://www.zakon.hr/z/85/Zakon-o-porezu-na-dohodak>. 


\section{DODATAK \\ IZRAČUNI POREZA I DOPRINOSA ZA OSAM HIPOTETSKIH JEDINICA U HRVATSKOJ}

\section{TABLICA A1.}

Stavke u izračunu pokazatelja poreznog opterećenja: 1. dio (Hrvatska, 2013.)

\begin{tabular}{lrrrr} 
& A-67-NC & A-100-NC & A-167-NC & A-67-2C \\
\hline 1. Bruto plaća & 8.202 & 12.303 & 20.505 & 8.202 \\
\hline 2. Doprinosi posloprimca & 1.640 & 2.461 & 4.101 & 1.640 \\
\hline 2.1. U prvi stup mirovinskog osiguranja & 1.230 & 1.845 & 3.076 & 1.230 \\
\hline 2.2. U drugi stup mirovinskog osiguranja & 410 & 615 & 1.025 & 410 \\
\hline 3. Porez na dohodak & 369 & 1.136 & 2.777 & 0 \\
\hline 3.1. Umanjenja porezne osnovice & 5.126 & 5.947 & 7.587 & 9.309 \\
\hline \multicolumn{1}{|c|}{ 3.1.1. Doprinosi posloprimca } & 1.640 & 2.461 & 4.101 & 1.640 \\
\hline 3.1.2. Osobni odbitak & 3.486 & 3.486 & 3.486 & 7.669 \\
\hline 3.2. Osnovica poreza na dohodak & 3.076 & 6.357 & 12.919 & 0 \\
\hline 4. Prirez porezu na dohodak & 44 & 136 & 333 & 0 \\
\hline 5. Ukupno porezi na dohodak & 413 & 1.272 & 3.110 & 0 \\
\hline 6. Doplatak za djecu & 0 & 0 & 0 & 727 \\
\hline 7. Neto plaća & 6.148 & 8.570 & 13.295 & 7.289 \\
\hline 8. Doprinosi poslodavca & 1.247 & 1.870 & 3.117 & 1.247 \\
\hline 9. Ukupna porezna davanja posloprimca \\
(= 2.1. + 5. - 6.)
\end{tabular}

Napomena: doprinosi posloprimca u drugi stup mirovinskog osiguranja ne ulaze u porezna davanja prema Taxing Wages metodologiji (OECD, 2014.). Stoga ta stavka nije uključena u 9.

Izvor: autorovi izračuni. 
TABLICA A2.

Stavke u izračunu pokazatelja poreznog opterećenja: 2. dio (Hrvatska, 2013.)

\begin{tabular}{|c|c|c|c|c|c|c|}
\hline & \multicolumn{3}{|c|}{$2 A-0 / 100-2 C$} & \multicolumn{3}{|c|}{$2 A-100 / 33-2 C$} \\
\hline & A1 & A2 & Ukupno & $\mathbf{A 1}$ & A2 & Ukupno \\
\hline 1. Bruto plaća & 12.303 & 0 & 12.303 & 12.303 & 4.101 & 16.404 \\
\hline 2. Doprinosi posloprimca & 2.461 & 0 & 2.461 & 2.461 & 820 & 3.281 \\
\hline 2.1. U prvi stup mirovinskog osiguranja & 1.845 & 0 & 1.845 & 1.845 & 615 & 2.460 \\
\hline 2.2. U drugi stup mirovinskog osiguranja & 615 & 0 & 615 & 615 & 205 & 820 \\
\hline 3. Porez na dohodak & 52 & 0 & 52 & 261 & 0 & 261 \\
\hline 3.1. Umanjenja porezne osnovice & 11.872 & 0 & 11.872 & 10.130 & 4.306 & 14.436 \\
\hline 3.1.1. Doprinosi posloprimca & 2.461 & 0 & 2.461 & 2.461 & 820 & 3.281 \\
\hline 3.1.2. Osobni odbitak & 9.412 & 0 & 9.412 & 7.669 & 3.486 & 11.155 \\
\hline 3.2. Osnovica poreza na dohodak & 431 & 0 & 431 & 2.174 & 0 & 2.174 \\
\hline 4. Prirez porezu na dohodak & 6 & 0 & 6 & 31 & 0 & 31 \\
\hline 5. Ukupno porezi na dohodak & 58 & 0 & 58 & 292 & 0 & 292 \\
\hline 6. Doplatak za djecu & 632 & 0 & 632 & 0 & 0 & 0 \\
\hline 7. Neto plaća & 10.417 & 0 & 10.417 & 12.831 & 0 & 12.831 \\
\hline 8. Doprinosi poslodavca & 1.870 & 0 & 1.870 & 1.870 & 623 & 2.493 \\
\hline $\begin{array}{l}\text { 9. Ukupna porezna davanja posloprimca } \\
(=2.1 .+5 .-6 .)\end{array}$ & 1.271 & 0 & 1.271 & 2.137 & 615 & 2.752 \\
\hline $\begin{array}{l}\text { 10. Ukupna porezna davanja posloprimca i } \\
\text { poslodavca }(=8 .+9 .)\end{array}$ & 3.141 & 0 & 3.141 & 4.007 & 1.238 & 5.245 \\
\hline 11. Ukupni trošak rada $(=1 .+8)$. & 14.174 & 0 & 14.174 & 14.174 & 4.725 & 18.899 \\
\hline 12. Neto prosječna porezna stopa $(=9 . / 1 . \times 100)$ & & & 10,33 & & & 16,78 \\
\hline 13. Neto prosječni porezni klin $(=11 . / 12 . x 100)$ & & & 22,16 & & & 27,76 \\
\hline
\end{tabular}

Napomena: (a) vidjeti napomenu uz tablicu A1; (b) A1 - prvi supružnik, A2 - drugi supružnik, "Ukupno" - zbroj za prvog i drugog supružnika.

Izvor: autorovi izračuni. 
TABLICA A3.

Stavke u izračunu pokazatelja poreznog opterećenja: 3. dio (Hrvatska, 2013.)

$2 A-100 / 67-2 C$

2A-100/33-NC

\begin{tabular}{|c|c|c|c|c|c|c|}
\hline & & & & & & \\
\hline & A1 & A2 & Ukupno & A1 & A2 & Ukupno \\
\hline 1. Bruto plaća & 12.303 & 8.202 & 20.505 & 12.303 & 4.101 & 16.404 \\
\hline 2. Doprinosi posloprimca & 2.461 & 1.640 & 4.101 & 2.461 & 820 & 3.281 \\
\hline 2.1. U prvi stup mirovinskog osiguranja & 1.845 & 1.230 & 3.075 & 1.845 & 615 & 2.460 \\
\hline 2.2. U drugi stup mirovinskog osiguranja & 615 & 410 & 1.025 & 615 & 2.015 & 2.630 \\
\hline 3. Porez na dohodak & 261 & 369 & 630 & 1.136 & 0 & 1.136 \\
\hline 3.1. Umanjenja porezne osnovice & 10.130 & 5.126 & 15.256 & 5.947 & 4.306 & 10.253 \\
\hline 3.1.1. Doprinosi posloprimca & 2.461 & 1.640 & 4.101 & 2.461 & 820 & 3.281 \\
\hline 3.1.2. Osobni odbitak & 7.669 & 3.486 & 11.155 & 3.486 & 3.486 & 6.972 \\
\hline 3.2. Osnovica poreza na dohodak & 2.174 & 3.076 & 5.250 & 6.357 & 0 & 6.357 \\
\hline 4. Prirez porezu na dohodak & 31 & 44 & 75 & 136 & 0 & 136 \\
\hline 5. Ukupno porezi na dohodak & 292 & 413 & 705 & 1.272 & 0 & 1.272 \\
\hline 6. Doplatak za djecu & 0 & 0 & 0 & 0 & 0 & 0 \\
\hline 7. Neto plaća & 15.699 & 0 & 15.699 & 11.851 & 0 & 11.851 \\
\hline 8. Doprinosi poslodavca & 1.870 & 1.247 & 3.117 & 1.870 & 623 & 2.493 \\
\hline $\begin{array}{l}\text { 9. Ukupna porezna davanja posloprimca } \\
(=2.1 .+5 .-6 .)\end{array}$ & 2.137 & 1.643 & 3.780 & 3.117 & 615 & 3.732 \\
\hline $\begin{array}{l}\text { 10. Ukupna porezna davanja posloprimca i } \\
\text { poslodavca }(=8 .+9 .)\end{array}$ & 4.007 & 2.890 & 6.897 & 4.987 & 1.238 & 6.225 \\
\hline 11. Ukupni trošak rada (= 1. + 8.) & 14.174 & 9.449 & 23.623 & 14.174 & 4.725 & 18.899 \\
\hline 12. Neto prosječna porezna stopa $(=9 . / 1 . \times 100)$ & & & 18,44 & & & 22,76 \\
\hline 13. Neto prosječni porezni klin $(=11 . / 12 . \times 100)$ & & & 29,20 & & & 32,95 \\
\hline
\end{tabular}

Napomena: (a) vidjeti napomenu uz tablicu A1; (b) A1 - prvi supružnik, A2 - drugi supružnik, "Ukupno” - zbroj za prvog i drugog supružnika.

Izvor: autorovi izračuni. 